Canadian Art Review

\title{
Bartolommeo Traballesi's Rain of Gold and the Poetics of Power in Francesco I's Scrittoio in the Palazzo della Signoria, Florence
}

\section{Corinne Mandel}

Volume 22, numéro 1-2, 1995

URI : https://id.erudit.org/iderudit/1072514ar

DOI : https://doi.org/10.7202/1072514ar

Aller au sommaire du numéro

\section{Éditeur(s)}

UAAC-AAUC (University Art Association of Canada | Association d'art des universités du Canada)

\section{ISSN}

0315-9906 (imprimé)

1918-4778 (numérique)

Découvrir la revue

Citer cet article

Mandel, C. (1995). Bartolommeo Traballesi's Rain of Gold and the Poetics of Power in Francesco I's Scrittoio in the Palazzo della Signoria, Florence. RACAR : Revue d'art canadienne / Canadian Art Review, 22(1-2), 53-79.

https://doi.org/10.7202/1072514ar

\section{Résumé de l'article}

La Pluie d'or de Bartolommeo Traballesi est plaçée de façon prééminente sur le mur principal du Scrittoio de Francesco $\mathrm{I}^{\mathrm{er}}$. Malgré sa grande visibilité, la peinture de Traballesi n'a pas fait l'objet d'étude savante. Cet article n'est qu'une première ébauche d'une étude plus approfondie sur le sujet et tente d'expliquer l'iconographie de la Pluie d'or pour la première fois. Le tableau contient un très grand nombre de motifs iconographiques significatifs qui, se combinant les uns aux autres, nous informent sur le règne exceptionnel des Médicis. Ce règne remonte à travers le $\mathrm{XIV}^{\mathrm{e}}$ siècle jusqu'à la fondation de Florence et revient par les ducs médicéens Alessandro et Cosimo $\mathrm{I}^{\mathrm{er}}$, au mécène du Scrittoio, le prince régent Francesco I ${ }^{\mathrm{er}}$. Enfin, cette étude montre, de façon non équivoque, que le Scrittoio est un manifeste politique, comme tous les autres programmes décoratifs commandés pour le Palais de la Seigneurie, le siège du gouvernement de Florence.
Tous droits réservés (C) UAAC-AAUC (University Art Association of Canada | Association d'art des universités du Canada), 1997
Ce document est protégé par la loi sur le droit d'auteur. L'utilisation des services d'Érudit (y compris la reproduction) est assujettie à sa politique d'utilisation que vous pouvez consulter en ligne.

https://apropos.erudit.org/fr/usagers/politique-dutilisation/ 


\title{
Bartolommeo Traballesi's Rain of Gold and the Poetics of Power in Francesco l's Scrittoio in the Palazzo della Signoria, Florence
}

\author{
Corinne Mandel, University of Western Ontario
}

For Gabrielle Langdon

\begin{abstract}
Résumé
a Pluie d'or de Bartolommeo Traballesi est plaçée de façon prééminente sur le mur principal du Scrittoio de Francesco I er

Malgré sa grande visibilité, la peinture de Traballesi n'a pas fait l'objet d'étude savante. Cet article n'est qu'une première ébauche d'une étude plus approfondie sur le sujet et tente d'expliquer l'iconographie de la Pluie d'or pour la première fois. Le tableau contient un très grand nombre de motifs iconographiques significatifs qui, se combinant les uns
\end{abstract}

aux autres, nous informent sur le règne exceptionnel des Médicis. Ce règne remonte à travers le XIVe siècle jusqu'à la fondation de Florence et revient par les ducs médicéens Alessandro et Cosimo I er , au mécène du Scrittoio, le prince régent Francesco ler. Enfin, cette étude montre, de façon non équivoque, que le Scrittoio est un manifeste politique, comme tous les autres programmes décoratifs commandés pour le Palais de la Seigneurie, le siège du gouvernement de Florence.
B artolommeo Traballesi's Rain of Gold is a little known painting currently located on the main, east wall of the famous Scrittoio of Francesco I de'Medici, ca. 1570-75 (figs. 1 and 2). It is consistently referred to in the literature by the misnomer Danaë because the myth that it represents concerns the Argive maiden's impregnation by Jupiter in the form of golden rain. While the painting is mentioned quite frequently in the literature on the Scrittoio, only one scholar has actually addressed its meaning: in 1976 Scott Schaefer devoted two pages of his dissertation to the Rain of Gold, most of which concerned the myth and an hypothesis as to what Francesco kept hidden in the cupboard behind the painting. ${ }^{1}$ In the course of his reconstruction of the Scrittoio, Schaefer also relocated Traballesi's sportello to the west wall, overseen by the tondo portrait of Duchess Eleonora of Toledo. All subsequent authors who have attempted reconstructions of the Scrittoio have likewise located the Rain of Gold on the west wall, dedicated to the element of air. ${ }^{2}$ Hence, these scholars are in agreement that the initial reconstruction of the Scrittoio by Giovanni Poggi in 1910 is faulty with regard to the placement of Traballesi's Rain of Gold, not to mention the locations of other paintings in the ensemble.

The most authoritative reconstruction of the pictorial programme of the Scrittoio to date is that published by Michael Rinehart in 1981, since it is based on notes penned by the Scrittoio's iconographer, Don Vincenzo Borghini, near the beginning of October $1570 .^{3}$ However, as Richard Scorza first recognized, Rinehart's decision to place the Rain of Gold on the air wall does not actually reflect the information contained on this page. ${ }^{4}$ The document reveals that Borghini had difficulty finding the proper place for this subject: having gone through the possibilities of placing it on the fire wall to the north (and crossing it out) and on the water wall to the south (and crossing it out), he fi- nally let it stand in the context of mining, and the sovereignty of Duke Cosimo I de'Medici, depicted in the lunette overseeing the earth wall to the east. Borghini did not even contemplate placing "la pioggia d'oro" on the air wall, at least not near the beginning of October 1570. As I shall demonstrate, Traballesi's painting belongs in its current location on the earth wall. In fact, all components of the main, earth wall, as well as the sculpture and painting at the northeast corner of the fire wall, are located in their proper place, as a result of Poggi's reconstruction of $1910 .^{5}$

Traballesi's Rain of Gold was created for a room populated with utterly gorgeous sculpted and painted nudes, undoubtedly for Francesco's private delectation (and instruction). It ought to have increased the population, especially when one thinks of Correggio's version of the subject, in which a langorous, supple Danaë reclines on her bed while a crafty Jupiter falls into her lap; Eros helps to consummate the act; and Cupid and an Amor sharpen the point of an arrow! ${ }^{6}$ Instead of following the tradition of Renaissance cabinet paintings, however, Traballesi focused attention on the groups of figures in the foreground, encircling King Acrisius to the left and building his fortifications at the right. He placed additional masons at the back of the foreground stage in order to lead the viewer into the sea- and cityscapes in the background at right, and ultimately into the cityscape at left. Traballesi placed Danaë's tower prominently at the centre of the foreground, making it function as the vertical axis for his plateau composition, but he made Danaë herself diminutive. Were it not for the golden rain falling from the top of the composition, one might not even notice her for some time. Thus, Traballesi's Rain of Gold is not about debauchery (no matter how exalted the perpetrator). Rather, it is a political metaphor concerning the effects of good and bad government. Following Borghini's ingenious conceit, Traballesi's Rain of Gold pits Medicean munificence against the misman- 
Figure I. Bartolommeo Traballesi, Rain of Gold, ca. 1571, Scrittoio of Francesco I, Palazzo della Signoria, Florence (Photo: Gabinetto Fotografico Soprintendenza alle Gallerie, Florence).

aged realms of others, both contemporaneous with and anterior to Cosimo I de' Medici's, all the while celebrating Francesco I, the patron of the Scrittoio. Though certainly less aesthetically pleasing than the lion's share of paintings in the Scrittoio, Traballesi's Rain of Gold is unquestionably the most complex carrier of meaning in the entire ensemble. As such, it is one of the most intellectually satisfying works of art in this gem of a room.

The essential source for Traballesi's painting is Ovid's Metamorphoses. In Book IV, Ovid recounts that

both [Cadmus and his wife] in their altered form found great comfort in their grandson, whom conquered India now worshipped, whose temples Greece had filled with adoring throngs. There was one only, Acrisius, the son of Abas, sprung from the same stock, who forbade the entrance of Bacchus within the walls of his city, Argos, who violently opposed the god, and did not admit that he was the son of Jove. Nor did he admit that Perseus was son of Jove, whom Danaë had conceived of a golden shower. And yet, such is the power of truth. Acrisius in the end was sorry that he had repulsed the god and had not acknowledged his grandson. The one had now been received to a place in heaven; but the other, bearing the wonderful spoil of the snake-haired monster, was taking his way through the thin air on whirring wings. ${ }^{7}$

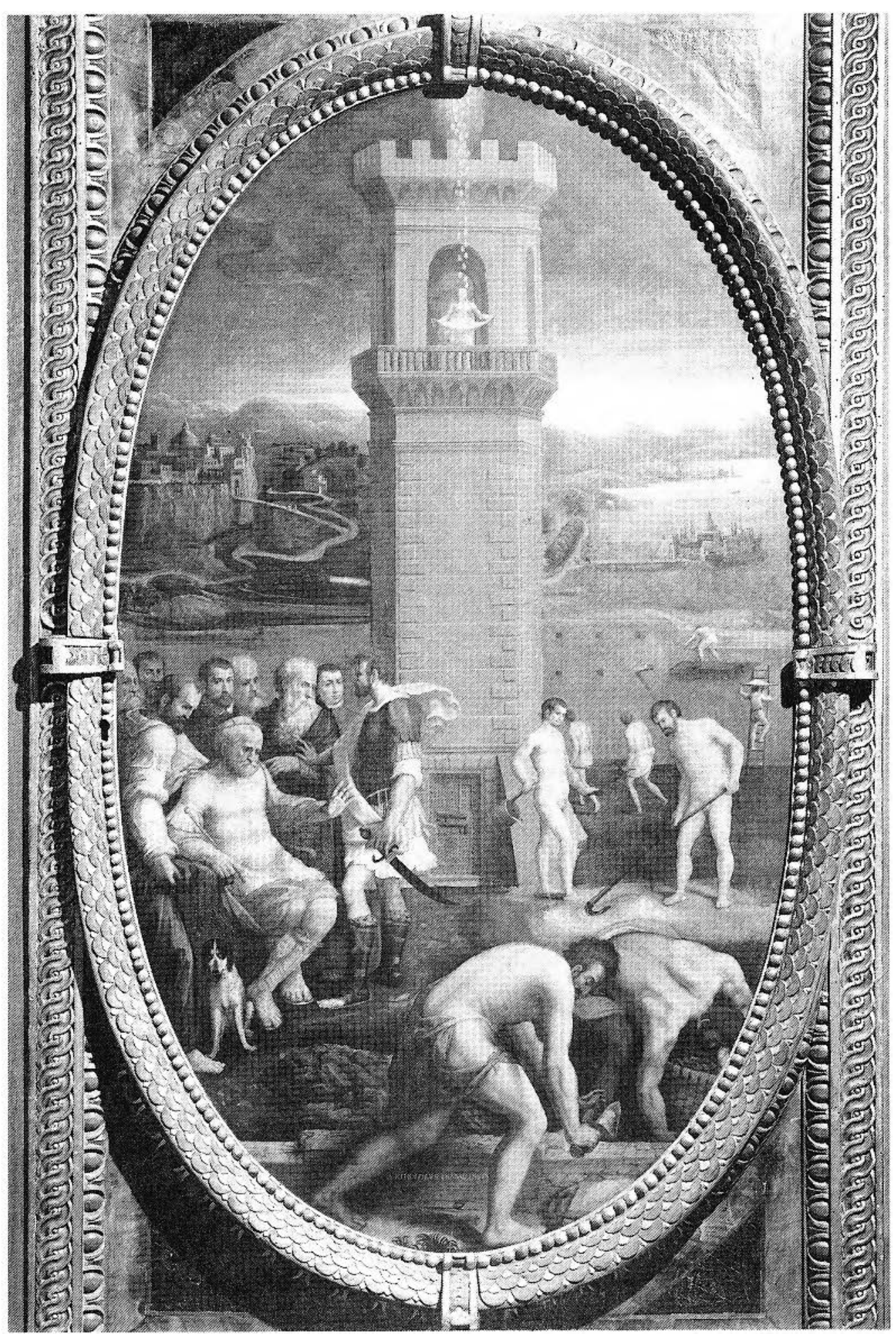


figure 2. Scrittoio of francesco I, view of eastern end, ca. 1570-1575, Palazzo della Signoria, Florence (Photo: Alinari/Art Resource, New York).

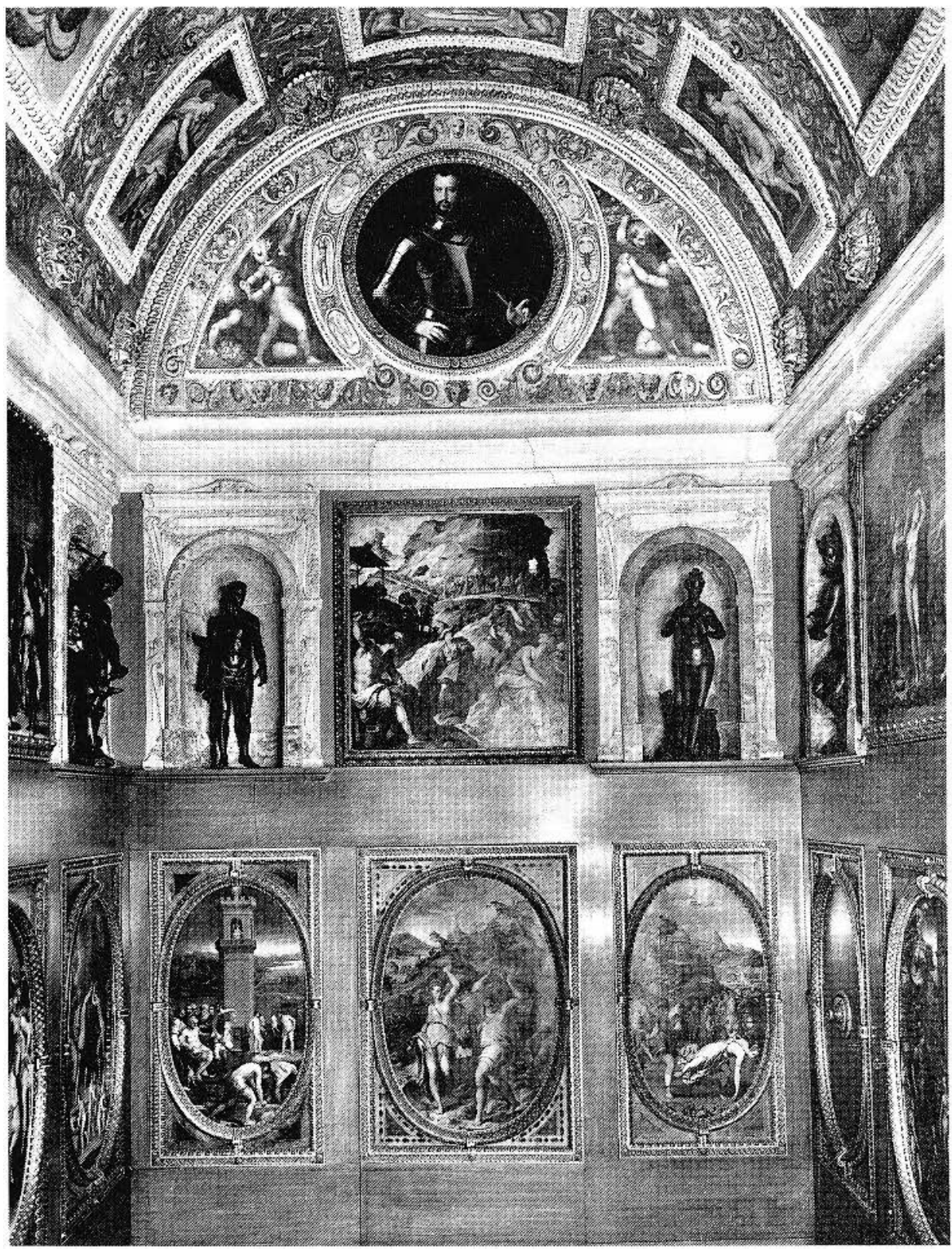

from Argos to Florence by following Borghini's subtle alterations. Moreover, he signals the relationship between the mythological Danaë and the city of Florence on the vertical axis of his composition.

Danaë's tower also bears a striking resemblance to the structure actually housing the Rain of Gold. It evokes the Palazzo della Signoria's tower not only in terms of the rusticated stone and balcony on which Danaë stands but also in terms of the bulwarks flanking the bronze portal, to which I shall return shortly (fig. 4). Traballesi's tower fitted with bronze accordingly indicates that Danaë is at once imprisoned and safeguarded. Stated otherwise, she is impregnated in the Bargello and given a haven at the seat of Tuscan government. But this is only a very general reading of the extremely pointed information contained in the Rain of Gold. By fitting the portal of Danaë's Palazzo della Signoria with bulwarks, Traballesi evoked a specific context for the myth because the bulwarks were constructed shortly after 11 September 1342 , and dismantled by 28 November 1349. To my knowledge, they were depicted only once before in the history of art, in the Expulsion of the Duke of Athens, a fresco

the Amores he describes both a "brazen tower" and a "chamber ... eternally strong with iron and rock." 9 Apollodorus speaks of Danaë forced into a subterranean chamber reinforced with bronze; Horace, of a maiden incarcerated in a brazen tower with oak doors; and Hyginus, in "a stonewalled prison." 10 Of all the descriptions, Traballesi's tower is closest to that contained in Hyginus' astrological treatise because it has distinct affinities with La Montanina, the tower of the Bargello (fig. 3). ${ }^{11}$ This is particularly evident on the upper reaches of his rusticated tower, where the primary action is taking place. Traballesi therefore follows antique myth in imprisoning Danaë, but he moves the location created ca. 1343-44 for the Carceri delle Stinche, the Florentine debtors' prison, and usually attributed to Andrea Orcagna (fig. 5). ${ }^{12}$

It is noteworthy that Traballesi drew on a work of art located in the city's "other" jail, since the myth of Danaë is about imprisonment, as the upper reaches of her tower amply illustrate. Moreover, the allusion to the debtors' prison evokes Giovanni Boccaccio's well known interpretation of the myth of Danaë as an allegory of greed. ${ }^{13}$ In such a context, one would expect Traballesi's Rain of Gold to connect an avaricious party, if not actually a debtor, with the golden rain. Since Traballesi rendered the bulwarks erected 
Figure 3. Bargello, begun 1251, Florence (Photo: Kunsthistorisches Institut, Florence).

by Walter of Brienne, Duke of Athens and Signore of Florence for ten months, from September 1342 until July 1343, then the Rain of Gold concerns events that happened centuries after Jupiter had visited Danaë, and over two hundred years before Francesco I commissioned Borghini to create a programme for his Scrittoio. Given that Danaë's tower is within her father's jurisdiction, then Acrisius must needs be the Duke of Athens' alter ego. He must needs be the greedy party. History bears out this analogy.

Following his election as "Conservadore" and "Capitano del Popolo," Walter of Brienne took up residence in the Palazzo della Signoria (then called the Palazzo dei Priori). In so doing, he displaced the Priors and departed from the acceptable conduct of his predecessor, the Duke of Calabria, who had resided in the Bargello during his tenure as Signore. The Duke of Athens wanted absolute control of Florentine government and spared neither feelings nor expense in trying to achieve this end. ${ }^{14} \mathrm{He}$ enlarged the Piazza della Signoria by annexing homes without offering any restitution whatsoever to the families concerned. He also planned an addition to the palace to house his guards and his household and fortifications for the entire complex, including the bulwarks that were actually constructed. The monies reserved for such renovations were a drop in the proverbial bucket: the Duke of Athens was a flamboyant spendthrift and a harsh tax man. Although the cessation of war with the Lucchese and the moratorium given to bankers generated revenue, by the end of his short tenure as $\mathrm{Si}$ gnore the Florentine coffers were empty. Moreover, he bequeathed a substantial public debt to his citizenry. Due to his mismanagement, Florence lost control over her territories of Arezzo, Pistoia and Volterra, and hence a further loss in revenue, not to mention political cachet. In addition, unemployment was on the rise, food was scarce, and as a result of the Duke's autonomy, the patriciate was alienated. As Giovanni Villani summarized his actions, "he usurped the liberty of the comune and people of Florence with deception and treachery." "As Ovid summarized them, "Acrisius in the end was sorry that he had repulsed the god and had not acknowledged his grandson." A unified populace expelled the Duke of Athens from Florence on Saint Anne's day, 26 July 1343. Thus, Traballesi's King Acrisiuscum-Walter of Brienne is about to face death at the hands of his grandson, Perseus, and expulsion from the city of Florence. He is the avaricious debtor connected with the

golden rain.

Traballesi's tower, which rises almost to the uppermost reaches of the composition from a central position in the foreground, is inherently phallic. In keeping with the sexual metaphor used by Ovid and Horace, Traballesi took care to complement the upward thrust of the tower with the golden rain falling into Danaë's lap. Borghini ensured that a further visual analogue would be present high above Traballesi's painting, in the crowning lunette of the eastern wall. Here, in the tondo portrait of the Duke of Tuscany, Cosimo sports an eye-catching codpiece that is at once bright red and erect! Since in one sense Traballesi's tower belongs to the Palazzo della Signoria, then Danaë is accepting the bounty of Duke Cosimo I, the overseer of the earth wall and, by implication, the alter Jove. ${ }^{16}$ She is accepting the bounty of the duke who took up residence in the Palazzo della Signoria in 1540, some two hundred years after the Duke of Athens had first made the move. Since the union between Jupiter-Cosimo and Danaë also takes place in the 
Figure 4. Palazzo della Signoria, begun 1299, Florence (Photo: Kunsthistorisches Institut, Florence).

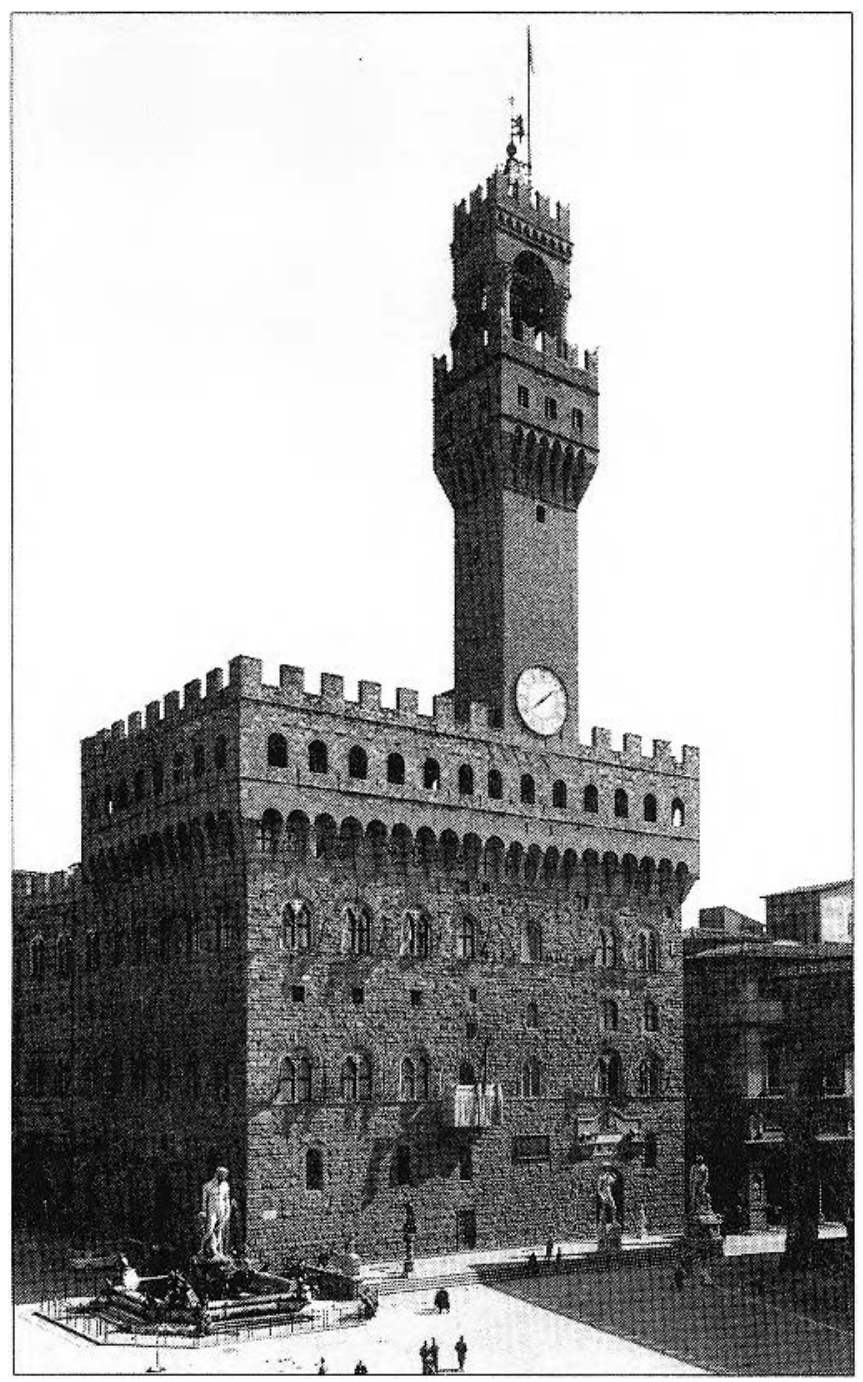

Bargello's tower, then Cosimo's suit of armour in the tondo portrait signals his militant care of the Tuscan state. Moreover, it intimates his control over the "other" residence of the Signore of Florence and, in the sixteenth century, seat of the Florentine jailer. Whereas economic hardship began during the tenure of the Duke of Calabria, only to be severely aggravated by the Duke of Athens, Duke Cosimo's seed ensures ample coffers for the city of Florence.

The figure of Danaë recalls Bartolommeo Ammannati's Fiorenza for the Fountain of Juno, begun in 1555 for the Sala Grande of the Palazzo della Signoria and subsequently earmarked, though apparently never installed, for the festivities honouring the marriage of Francesco I and Giovanna of Austria in 1565 (fig. 6). In both, the women look upward: Fiorenza is looking toward God, as befits a Christian city, while Danaë looks toward Jupiter as the golden rain. ${ }^{17}$ Since Danaë ultimately looks toward the tondo portrait of Cosimo I from a conflated Bargello and Palazzo della
Signoria, then she is accepting the bounty of Jupiter-Cosimo as a Christian Danaë-Fiorenza. In this context Traballesi's Rain of Gold is intimately related to the Jupiter and Danaë tapestry that adorned the Sala di Giove in the Palazzo della Signoria and that is currently known through a drawing executed by Giorgio Vasari in $1557 .{ }^{18}$ In a passage penned regarding this tapestry, Vasari indicates that Danaë is receiving the beneficence of Jupiter-Cosimo: "These, my lord [Francesco], are those who are persuaded to act on the duke's behalf by the kindness and liberality he shows thrcugh gold and gifts. Entering the most private and impossible places as a rain of gold, the duke draws everyone to his service to do him honour by gifts and love."19 Just as the all-powerful Jupiter travels to impossible places (i.e., Danaë's lap) to bestow his beneficence, so Cosimo's citizenry loves and honours their omniscient ruler. Since Cosimo's citizenry is Christian, it is but a short step to recognize the Christian parallels implied in these depictions of Danaë. Traballesi's polysemous tower, in particular, evokes the tower of the Immaculata so that Danaë's impregnation by the golden rain can only signal Christ's Incarnation. The radiance of the golden rain reinforces such a reading because Christ is Apollo-Sol. Such Christian symbolism is furthered in terms of the historical reality of Traballesi's tower. Following the Duke of Athens' expulsion, the republicans decorated the Palazzo della Signoria's portal, now devoid of bulwarks, with the cross of the Florentine citizenry flanked by Florentine fleurs-de-lys and lions on consoles. ${ }^{20}$ And in 1528, the republicans added a crowning inscription to this portal celebrating Christ and the Virgin as the King and Queen of Florence. ${ }^{21}$ Hence, it does not take a great stretch of the imagination to infer that Traballesi's Rain of Gold celebrates Florence's foundation and the birthday of its patron, Francesco-Perseus, for both events occurred on $25 \mathrm{March}$, the Feast of the Annunciation. ${ }^{22}$

Fiorenza carries flowers in her apron because Florence is the city of Flora, goddess of springtime; Danaë lifts her apron to accept Jupiter's engendering seed. The flowers in Fiorenza's apron reinforce the symbolism of the Incarnation because they evoke the flowers given to the Virgin on the Feast of the Annunciation. They also suggest the verdant springtime enjoyed in Florence on each anniversary of her foundation, as during Medicean rule year-round, hence recalling a well worn topos of Medicean panegyric (compare fig. 17). ${ }^{23}$ The gold falling into Danaë-Fiorenza's lap likewise indicates her possession of nature's riches. In the Christian sense, Danaë is like the Virgin, chosen to carry the corporeal body of the treasure which is Christ. In the antique, pagan sense, Danaë's female body is a treasure chamber by its very nature. ${ }^{24}$ Like her tower, then, Danaë 
Figure 5. Andrea Orcagna, attr., Expulsion of the Duke of Athens, ca. 1343-44, ex-Carceri delle Stinche, Saletta, Palazzo della Signoria, Florence (Photo: Alinari/Art Resource, New York).

contains a treasure trove: at once Francesco I de'Medici-Perseus-Christ and the Medicean purse (not to mention the Guardaroba, and Scrittoio itself).

The differences between Ammannati's Fiorenza and Traballesi's Danaë are as instructive as the similarities. Fiorenza wears a chain across her chest that bears a striking resemblance to a quiver strap. In tandem with her short skirt and arrows, Detlef Heikamp has shown that this chain assimilates Fiorenza to Apollo's twin sister Diana. Although Traballesi's Danaë was clearly stripped of her jewels before Acrisius shut her up in the tower, Borghini shows the viewer that she nevertheless carries comparable meaning (a meaning already implicit in her assimilation to the Virgin Mary). He does so by locating another tower on the earth wall, this time crowning Ammannati's Ops (Mother Earth, or Mother Nature), a bronze situated in the niche at the southeastern end (fig. 2), and echoing the artist's own Ceres for the Fountain of Juno, except for the tell-tale crown. Since both Danaë's tower and Ops' crown are crenellated, the visual evidence indicates that Danaë and Ops are alike. Moreover, in Sebastiano Marsili's Atalanta and Hippomenes (fig. 7),

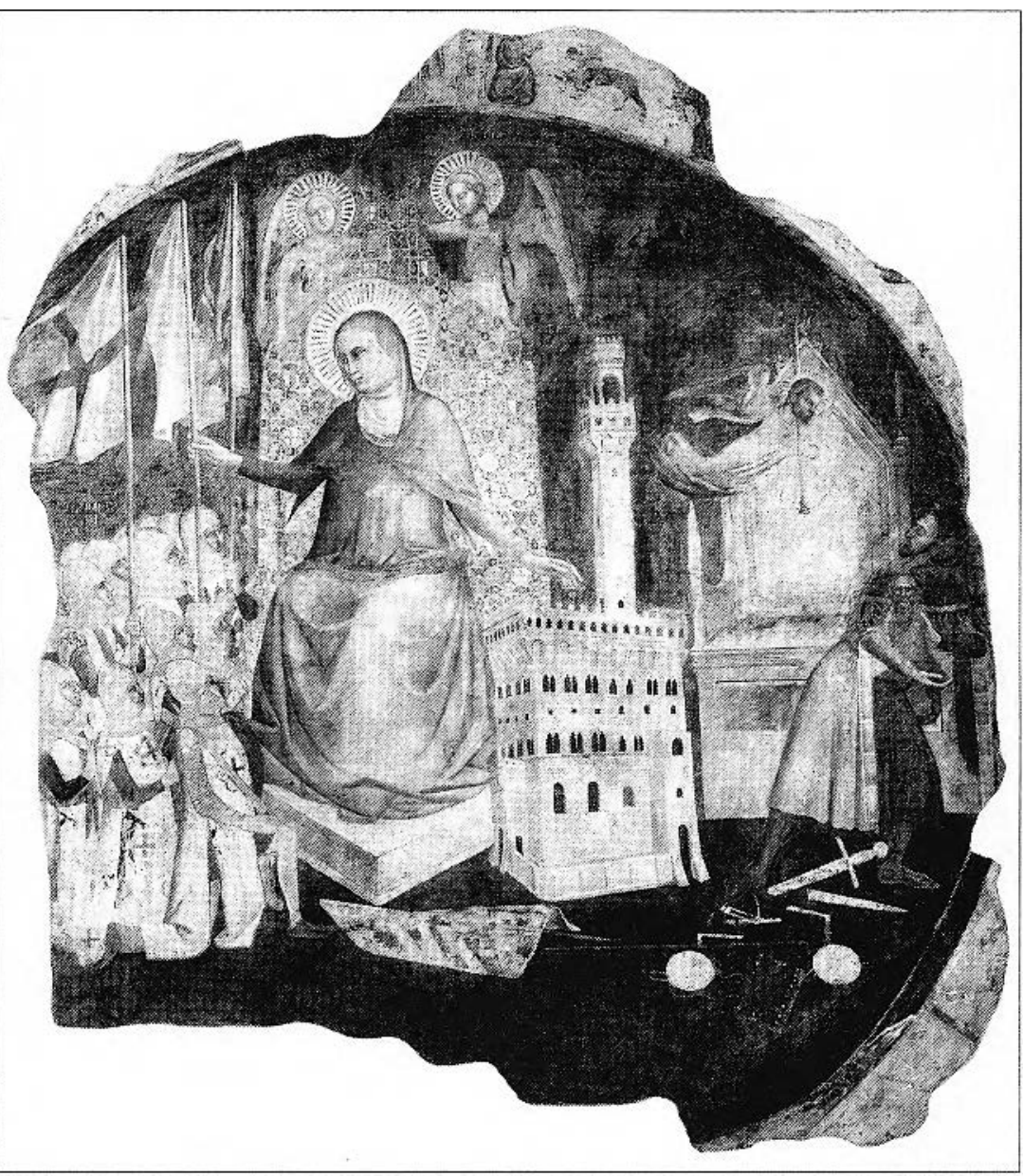
the pendant to the Rain of Gold on the earth wall, a turretcrowned, airborne Ops occupies the same position as Traballesi's Danaë, at the top of the composition, while both figures are collocated with a burst of light. Both the sculpture and the painting at the south-eastern end of the earth wall therefore indicate that Danaë is akin to Mother Earth.

Now, it is well known that Mother Earth enjoys centre stage on the Scrittoio's frescoed vault, with Francesco Morandini's Ephesian Mother Nature Giving the Stone to Prometheus. Borghini therefore forged an intimate connection between Traballesi's Rain of Gold, Ammannati's Ops, Marsili's Atalanta and Hippomenes, and the Scrittoio's centre-piece. Just as Cosimo's tondo portrait reinforces Jupiter's "true" identity and the Tuscan location of the action in the Rain of Gold, so additional components of the eastern wall enable the viewer to recognize Diana as Danaë's alter ego. Moreover, Danaë's tower - and impregnation, to which I shall return - provide the salient clues required for such a reading.

As Julian Kleimann discovered, Borghini was thinking in terms of the Scrittoio's centre-piece in another context:

on the cover of Borghini's fifty-fifth notebook, which treats the curative powers of plants, there is an impresa featuring the mural-crowned Mother Nature feeding creatures from her abundant breasts. ${ }^{25}$ But whereas Mother Nature wears her crown in the impresa, in Morandini's version Mother Nature wears a Pompadourian coiffeur, as it were. Clearly, then, Borghini reserved the theme of fortification for the main wall of the Scrittoio, with Ammannati's Ops, Marsili's Ops, and Traballesi's Danaë-Fiorenza-Diana and AcrisiusWalter of Brienne. He no doubt did so because this theme is fundamental to the myth of Danaë: it was the Great Mother who first taught men how to build walls so that they could keep peace within their state and keep the enemy without. ${ }^{26}$ As Acrisius directs the work of the masons in the foreground, in order to safeguard his daughter's virginity and preserve his own life, he is accordingly drawing on the knowledge that Mother Nature has given him. Further, as the Emilian mythographer Vincenzo Cartari explained, Mother Nature gave her mural crown to the emperor, who built walls to safeguard his subjects from inimical forces. ${ }^{27}$ Borghini was well aware of this fact, for on 
Figure 6. Bartolommeo Ammannati, Fiorenza, I555 ff., Fountain of Juno, Bargello, Florence (Photo: Kunsthistorisches Institut, Florence).

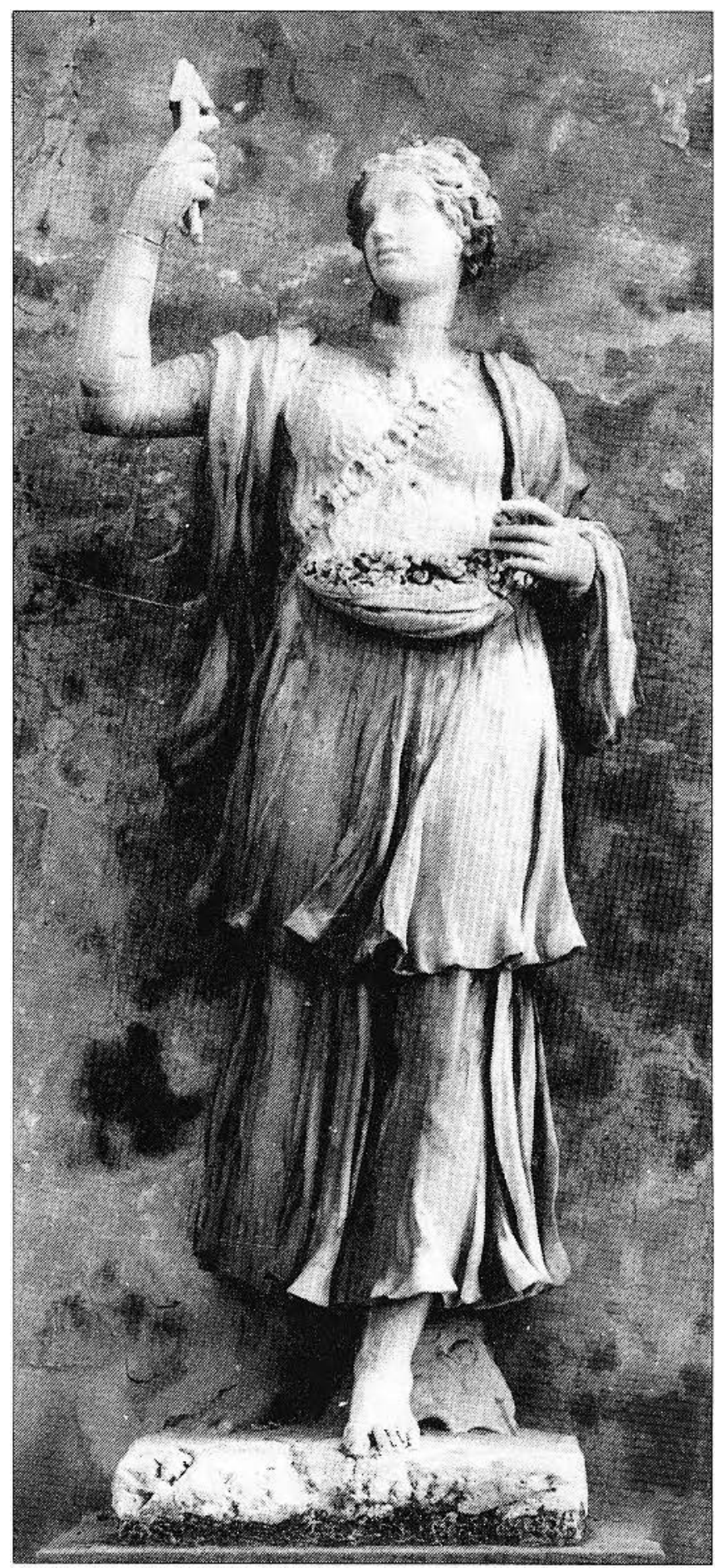

the cover of his seventy-second notebook, containing lives of emperors and histories of their colonies, he drew an impresa with a corpo featuring masons building a wall, and the anima "EX MVLTIS VNVM [from many, one]." (fig. 8). ${ }^{28}$ What is more, the stances of Borghini's masons, the partially built wall, and the rose in the tondo crowning the impresa are remarkably close to the gestures of Traballesi's masons, his partially built wall, and the rain that ultimately falls into Danaë's lap from the tondo of the earth wall's crowning lunette. One may therefore conclude that the masons building walls on both sides of the Bargello-Palazzo della Signoria are working on order of Danaë-FiorenzaDiana, who has taught them how to defend her Tuscan state. As Borghini's own manuscript cover would suggest, they are also working on order of an emperor.

Ammannati's Fiorenza carries a bundle of arrows in her right hand, and has placed her helmet at her feet. Danaë is bereft of such attributes, but not of the meaning they convey. In one sense, her "fortezza" lies in the fortifications that are being constructed on her father's orders, and on her own, as Danaë-Fiorenza-Diana. ${ }^{29}$ In another sense, it lies in Vittorio Casini's Forge of Vulcan, the adjacent painting on the fire wall, in which cupids play with arrows and a helmet hangs ready for use - by association, for Danaë-Fiorenza's use (as for the use of the well-endowed and armoured Cosimo in the earth wall's crowning lunette!). Similarly, it lies in Vincenzo de Rossi's adjacent sculpture, in which Vulcan creates another arrow for Danaë-Fiorenza-Diana's fasces, recalling those held by Venus-Fiorenza in Vasari and Cristofano Gherardi's Allegory of Fire upstairs, in the Sala degli Elementi of the Palazzo della Signoria. ${ }^{30}$ Borghini therefore continued Danaë's identification as Fiorenza around the corner of the Scrittoio's north-eastern end.

The final visual difference between Traballesi's Danaë and Ammannati's Fiorenza is that the chain worn by Ammannati's sculpture belongs to the Order of the Golden Fleece. On the one hand, the cupids in the Forge of Vulcan are playing with a chain so that, by association, Casini's painting contains an allusion to Danaë's missing ornament. On the other hand, there is a painting in the Scrittoio in which the chain of the Order of the Golden Fleece is actually depicted: it is worn by King Schoenus in Marsili's Atalanta and Hippomenes (fig. 7), the pendant to the Rain of Gold. As Schaefer has recognized, King Schoenus (centre right) is actually a portrait of Grand Duke Cosimo I, so that Hippomenes becomes Francesco I, and Atalanta, his bride Giovanna of Austria. ${ }^{31}$ Cosimo's possession of the chain of the Order of the Golden Fleece in Marsili's painting therefore acts as a foil for Traballesi's Danaë. Since Danaë receives Jupiter-Cosimo's golden rain, she also receives the honour of belonging to this exalted order. Given that Cosimo was admitted into the Order of the Golden Fleece in July 1545, but Francesco not until forty years later, in July 1585, the chronology actually helps to reinforce both Danaë's intimate relationship with Cosimo and the rain of gold as symbolic of Francesco's conception. ${ }^{32}$ 
Figure 7. Sebastiano Marsili, Atalanta and Hippomenes, ca. 1571, Scrittoio of Francesco I, Palazzo della Signoria, Florence (Photo: G. F. S. G., Florence).

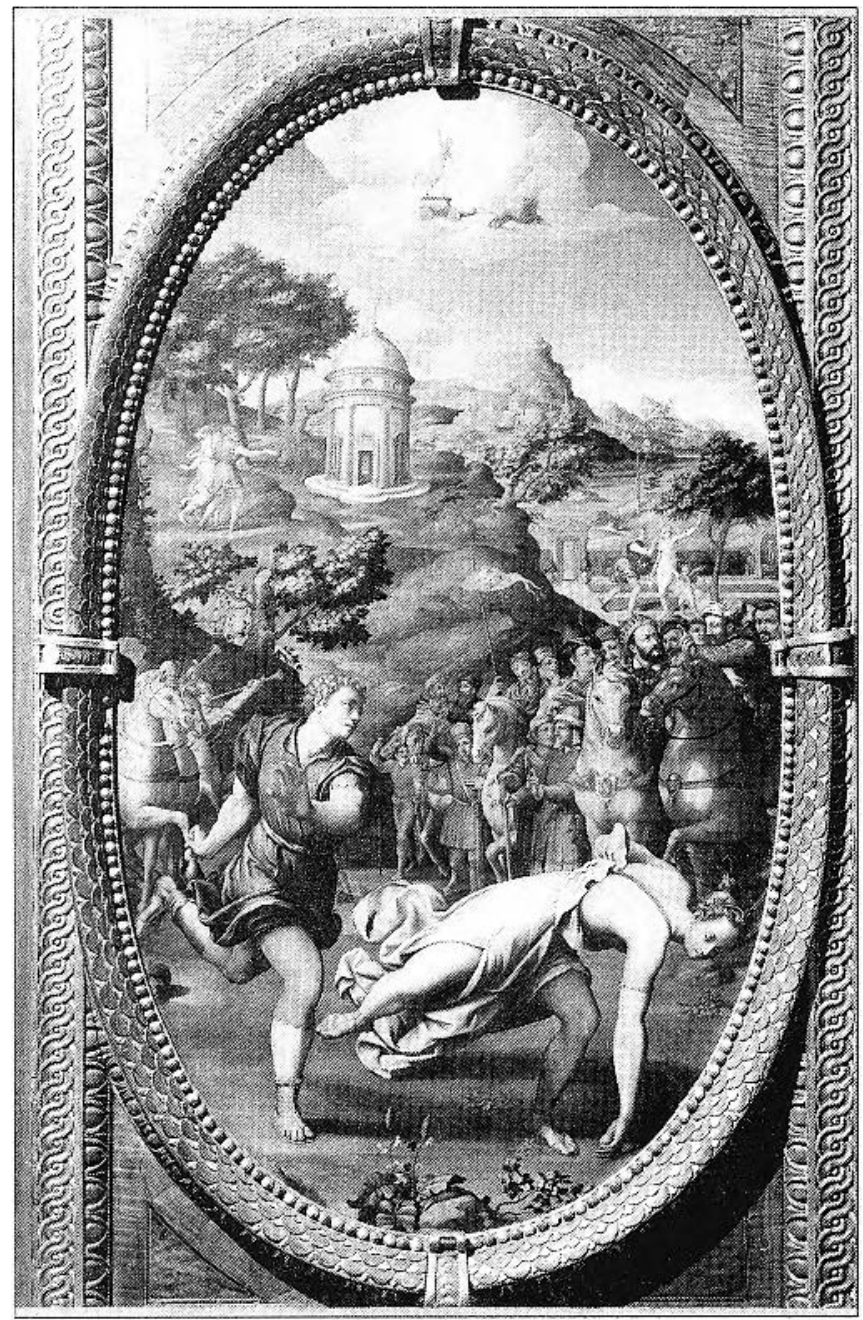

On Ammannati's Fountain of Juno, Fiorenza was paired with Temperanza, a personification accompanied by the dolphin and anchor of Cosimo's festina lente [make haste slowly] impresa (fig. 9). In view of the relationship between Traballesi's Rain of Gold and Fiorenza, not to mention Ammannati's Ops and Ceres, it is not surprising that Marsili's Atalanta and Hippomenes contains the tortoise and sail of Cosimo's festina lente impresa - amusingly held by a manifestly exhausted rider. Clearly, Borghini took Ammannati's - and Cosimo Bartoli's - Fountain of Juno and instructed Vasari and his artists to range it in altered form across the eastern end of the Scrittoio. In so doing, he echoed the fountain's pendant niche sculptures in the pendant paintings on the main wall of the Scrittoio. Moreover, he managed to incorporate each of Fiorenza's attributes at the eastern end of the Scrittoio, overseen by Duke Cosimo I de' Medici.

In the final analysis, Borghini's difficult decision to locate the Rain of Gold on the Scrittoio's earth wall was surely calculated to evoke the ancient notion that a woman's womb
Figure 8. Vincenzo Borghini, "EX MVLTIS VNYM", notebook cover, Biblioteca Nazionale Centrale, Florence, ms. II.X.II3 (Photo: Maurizio Schioppetto, Florence).

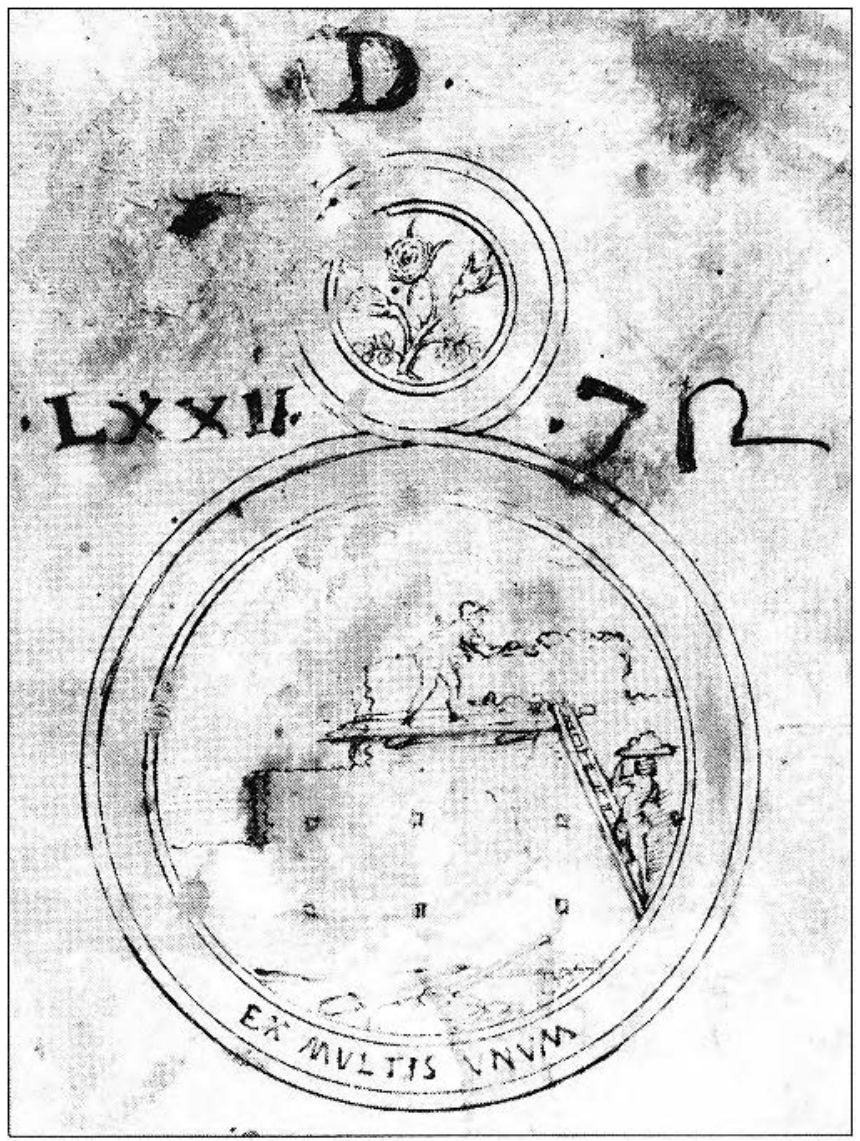

is like the earth. After all, the very title that Borghini gave to the painting indicates that Danaë is being watered, as rain quenches the earth's thirst. Herein lies the connection between Ammannati's Ops and the impregnated Danaë. Borghini reinforced this notion that Danae is like the earth by locating Domenico Poggini's sculpture of Plutus in the niche directly above Traballesi's painting (fig. 2). Although Poggini did not depict his god of the earth's riches as a blind man, he did conform to Borghini's - and Lucian's - general characterization of Plutus as "full of thoughts as are the avaricious" by outfitting him with a copper vase in his left hand. ${ }^{33}$ Hence, Plutus' now lost copper vase was like Danaë, a receptacle for gold.

Plutus' stance actually echoes that of Ammannati's Temperanza (both of which draw on Michelangelo's David). By locating Poggini's Plutus above Traballesi's Danaë, Borghini therefore presented the altered Fountain of Juno on the vertical axis of the north-eastern end of the earth wall, as a foil to the pendants ranged horizontally across the wall. In this way, Borghini seems to have been commenting on Jupiter-Cosimo's amassing of gold by transforming the traditional personification of Temperance, who pours water from one vessel into the wine of another, into 
Figure 9. Bartolommeo Ammannati, Temperanza, 1555 ff., fountain of Juno, Bargello, Florence (Photo: Alinari/Art Resource, New York).

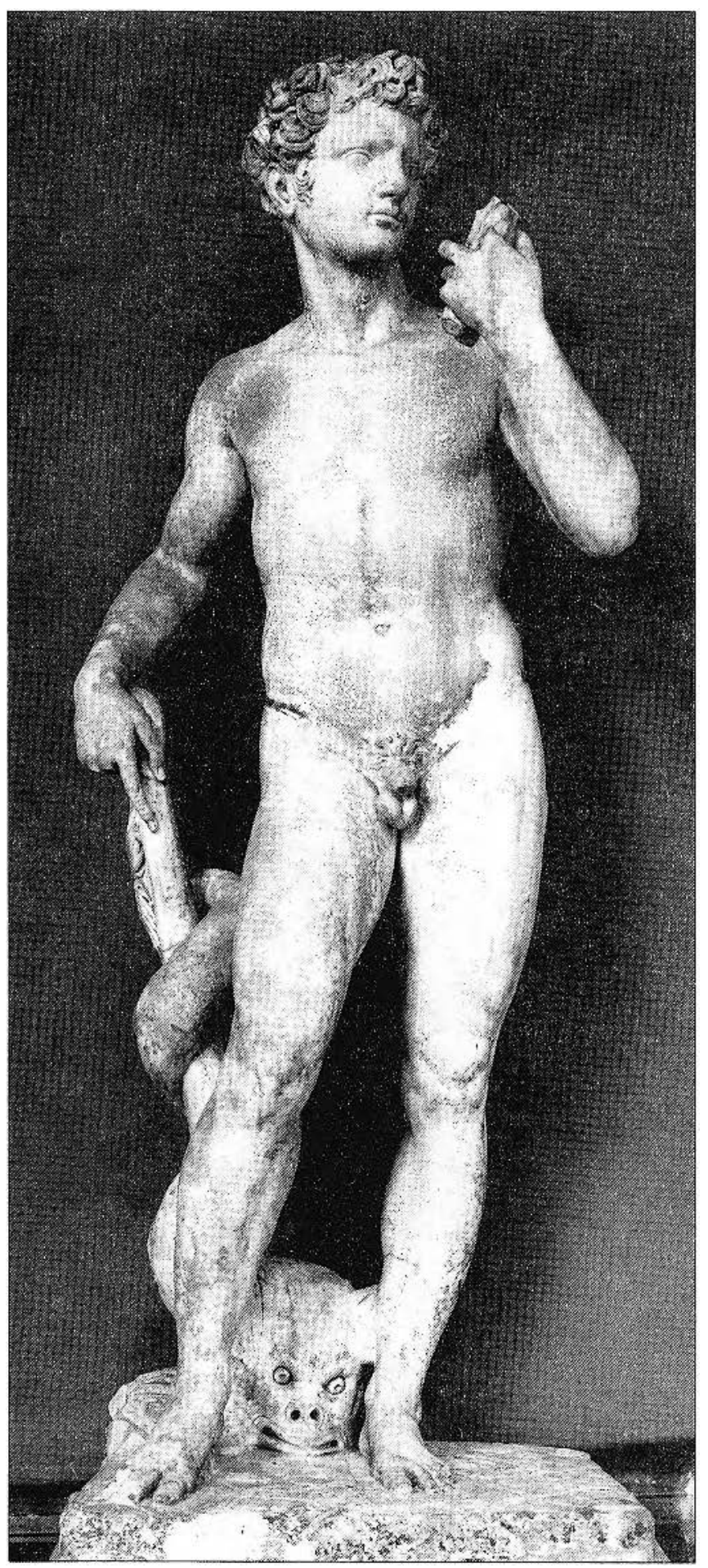

the greedy Plutus! At the same time, the collocation of Plutus and the armoured Cosimo I in the lunette above recalls an Athenian statue of Peace holding the god Plutus on her lap, described and interpreted by Cartari as emblematic of the fact that "peace conserves riches, and war dissipates them." 34
One might even say that such an interpretation summarizes Traballesi's Rain of Gold, especially when keeping in mind the imperial masons on Borghini's notebook cover, as in Traballesi's foreground. ${ }^{35}$

By placing Plutus' copper vase directly above Danaë's lifted apron, Borghini was also drawing on the age-old notion that a woman's body is like a jar or vessel, a notion as implicit in Ammannati's Fiorenza as in Correggio's Danaë. In Traballesi's Rain of Gold, the analogy between the womb and an upturned jar with two handles, conveyed early on by Greek physicians, finds visual form in the way that Danaë holds out the sides of her apron so that she may catch the golden "semen" in her concave "uterus." ${ }^{6}$ Moreover, the analogy finds confirmation in a typological reading of the Song of Songs, in which the Virgin carrying Christ within her womb is compared to a vase of balsam, a vase of Grace. ${ }^{37}$ Indeed, as Vasari describes her in his Ragionamenti, the fifth power, or Sephiroth, painted on the soffit of the Sala degli Elementi, holding a "large vase turned downwards, full of gems, gold and silver vases, necklaces [including that of the Order of the Golden Fleece] and mitres of popes, crowns of emperors and kings ...", embodies "the grace of God." Just as Plutus' copper vase contains the earth's most prized treasure, so Traballesi's Danaë receives a most precious seed from the metamorphosed king of the gods-Cosimo I, the necessarily avaricious state treasurer.

Traballesi created further visual analogies between his Rain of Gold and Poggini's Plutus, which suit the specific context of his narrative. He gave the figure pouring water from a bucket before the bulwark of Danaë's tower the same stance as Poggini's sculpture (and Ammannati's Temperanza). He also positioned Acrisius' upper torso in the same manner as that of both Plutus and this nude. Moreover, he gave the same stance to the manifestly aggressive soldier. Traballesi then gave the elegantly draped figure at the far left, lifting his left hand in the manner of the king, a stance similar to that of the other nude in the painting. He therefore presented a parallel between the two unusually nude masons preparing mortar for Danaë's safekeeping and Acrisius, the soldier and his aide, who apparently oversee the Tuscan state.

Just as the tower's bulwarks conjure a specific period in Florentine history, so Acrisius' aide points to another, particular context, for he has the distinct features of Cosimo I. The receding hair line, the moustache and beard, and the aquiline nose all point to such an identification, though Cosimo's manifestly irate glare gives one pause. While unusual in Medicean art, Cosimo I was presented in such a manner in Vasari and Giovanni Stradano's Triumph of Cosimo I at Montemurlo, created between 1556 and 1559 
Figure 10. Giorgio Vasari and Giovanni Stradano, Triumph of Cosimo I at Montemurto, ca. 1556-59, Sala di Cosimo I, Palazzo della Signoria, Florence (Photo: Alinari/Art Resource, New York).

for the Sala di Cosimo I, just steps away from the Scrittoio (fig. 10). In that context, the Duke faces the fuorusciti, already bound and about to be thrown in jail. The similarity between Vasari's Cosimo and Traballesi's is not fortuitous, as I shall demonstrate later in my analysis.

By giving Cosimo a pose similar to that of the nude figure with the very long implement, Traballesi pointed to the relationship between Danaë's tower, the golden rain, and the wellendowed Cosimo in the tondo portrait above! In other words, he provided another visual interpretation of the military metaphor conveyed by the union of Jupiter and Danaë in her signorial prison. The black object that Cosimo holds in his right hand, most certainly a purse, serves to reinforce his identity as the transmuted golden rain in the upper reaches of the painting. It also confirms his status as an alter Plutus and state treasurer. Whereas King Schoenus-Cosimo I rules the realm in Marsili's pendant Atalanta and Hippomenes, Borghini evidently instructed Traballesi to demote the Grand Duke of Tuscany in his Rain of Gold. An analysis of Acrisius' form will shed further light on the relationship between the king and his Medicean state treasurer.

In a sense, the sad look on King Acrisius' face in tandem with his crossed legs recall Michelangelo's

Penseroso in the Medici Chapel at San Lorenzo. Rather than resting his left hand on his chin, Acrisius holds out his hand in order to direct the work of the masons in the foreground. The sceptre he holds in his right hand evokes the baton held by the Bastonière, the Penseroso's pendant. It also reinforces his identification as Danaës father, the King of Argos, not to mention Walter of Brienne, Signore of Florence, who was given the baton of command as Capitano del Popolo. ${ }^{39}$ Acrisius' crown reinforces the fact that he is King of Argos. At the same time, it is a pathetic excuse for a crown when compared with the grand ducal crown worn by King Schoenus-Cosimo I in Marsili's Atalanta and Hippomenes (fig. 7). To my eye, it is almost like a crown of thorns. The king's sad demeanour together with his decidedly bad posture and thorny crown indicate that he is a melancholic ruler. The rather mangy dog contributes to this symbolism of melancholy. ${ }^{40}$ One is therefore reminded that, according to Ovid, "Acrisius in the end was sorry that he had repulsed the god and had not acknowledged his grandson." Positioned between the feet of Acrisius and Cosimo, the dog also suggests the fidelity shared by the ruler and his Medicean aide, although his unhealthy state prompts one to question the nature of the relationship between the two. Indeed, the inverted triangle formed by the sickly dog, slumped king and irate Cosimo is inversely related to the triangle whose apex celebrates Danaë and the golden rain 
and whose sides each feature a virile Cosimo I.

According to the evidence presented in the Rain of Gold, the contemporaneous context that Borghini conflated with the myth of Danaë and the reign of the Duke of Athens ought to have taken place at some time in the fifth decade of the sixteenth century. Cosimo moved into the Palazzo della Signoria at the beginning of the decade. His son Francesco was born the following year. Of course, the imperial symbolism of the Rain of Gold points to Florence's foundation. But since Divine Providence chose to give Eleonora and Cosimo their first male child on the anniversary of their city's foundation, then the symbolism reverts back to the Scrittoio's patron once again. Together with the imperial symbolism, Cosimo's manifest presence in the narrative indicates that the context ought to entail contemporaneous politics bound up with the empire. Since Charles $\mathrm{V}$ had appointed Alessandro de'Medici "Head, Keeper and Protector of the Republic of Florence" in 1531, following suit with Cosimo in 1537, and since Charles V admitted Cosimo into the Order of the Golden Fleece in 1545, then the Holy Roman Emperor ought to play a role in the Rain of Gold. ${ }^{41}$ Further, Cosimo's more youthful appearance in the tondo portrait than in reality, in tandem with his equestrian suit of armour, indicate that a context ca. 1560 ought to be forthcoming. ${ }^{42}$ Hence, the Rain of Gold ought to have additional resonances that are not all that far removed from the date in which Borghini devised the Scrittoio's programme.

In his Istoria de' suoi tempi, Giovambatista Adriani explains that around 1539 Duke Cosimo I turned his attention to Piombino, an important coastal town south of Livorno, then under imperial jurisdiction. ${ }^{43}$ Though certainly not without designs of his own for this territory, Cosimo assisted the Signore of Piombino and Charles V in ensuring Piombino's safety. By 1541, as Cosimo was sending money and guards to safeguard Piombino from foreign invaders, especially from the terrible Turk, Khair ed-din (Ariadeno Barbarossa), his wife Eleonora was giving birth to their first-born son Francesco, and baptismal celebrations were under way. As Adriani reports, "At the same time, with great pomp and joy, the baptism of his first born was celebrated. [Francesco] was held at the sacred font by Don Giovanni di Luna in the name of the emperor, and by another lord in the name of the Queen of Hungary, giving great pleasure to the whole city [of Florence]." 44 If my reading of Traballesi's painting to this point is tenable, then the essential historical confluence it represents ought to concern Francesco's birth - and baptism, notably on the anniversary of the 1537 Battle of Montemurlo - and the state of Piombino.
Piombino was a perennial target for foreign attacks, since strategically placed on the Tyrrhenian Sea. It is perhaps best known to art historians due to Leonardo da Vinci's designs for its fortifications, which he carried out in 1504 for Jacopo IV d'Appiano, Signore of Piombino. The d'Appiano family had enjoyed political power since 1392, when Jacopo I d'Appiano murdered Pietro Gambacorta, the Signore of Pisa. In usurping Gambacorta's post, Jacopo I was able to take control of Piombino and the islands of Elba, Pianosa and Montecristo, which were at that time under Pisan rule. The ignoble beginnings of the d'Appiani were not rectified as time went on. They were not only still decadent by the sixteenth century but they had also become incapable egoists. Thanks to the feudal investiture given to Jacopo IV in 1510 by the Emperor Maximilian, and reinstated for Jacopo V in 1520 by the Emperor Charles V, the d'Appiani were able to rely on imperial protection in order to safeguard their territory from the Turks, Genovese, Neapolitans and French, not to mention the papacy. ${ }^{45}$

The Signore of Piombino in 1541 was Jacopo V d'Appiano. His wife, Lena (or Elena) Salviati, was Maria Salviati's sister. Hence, Jacopo V d'Appiano was Cosimo I's uncle. There was absolutely no love lost between the duke and his uncle. Time and again, Adriani relates that Jacopo $\mathrm{V}$ kept demanding money from his nephew, while refusing to lend a hand with the defense of his state. His wife only exacerbated the situation. True, Jacopo's cousin, Ferrante d'Appiano, rented his alum mines on the island of Elba to Cosimo in 1542, but this act of decency was the result of Ferrante's greater animosity towards the Farnese Pope Paul III. It was also in 1542 that Barbarossa sacked the island of Elba and demanded that Jacopo $V$ return the son of an Elban woman and the Tunisian Sinam Bassà, known as Guido Corsale (or Giudeo delle Costiere of Tunis), then within d'Appiano's jurisdiction (a male Danaë, or so it would seem). ${ }^{46}$ By 1543 , Cosimo had posted Otto da Montauto with some three hundred infantrymen in Piombino; he had sent his commissario generale Girolamo degli Albizzi to try to reason with Jacopo V; and he had determined that the walls of Piombino, which had been badly damaged by "le pioggie del verno," the winter rain, were in need of repair, and so sent "Architects, and master masons from the dominion of Florence, and a large number of countrymen" to rectify the situation. ${ }^{47}$ As Adriani further relates, "in Piombino one found neither men nor instruments to assist with the work, and money continued to be sent to the lord so that he might pay the soldiers and the builders." 48

As Borghini clearly recognized, Cosimo's regard for Jacopo $\mathrm{V}$ was akin to that of the Florentines for the Duke 
Figure II. Giorgio Vasari and Giovanni Stradano, Cosimo I elected Duke of Iuscany, ca. 1556-59, Sala di Cosimo I, Palazzo della Signoria, Florence (Photo: Alinari/Art Resource, New York).

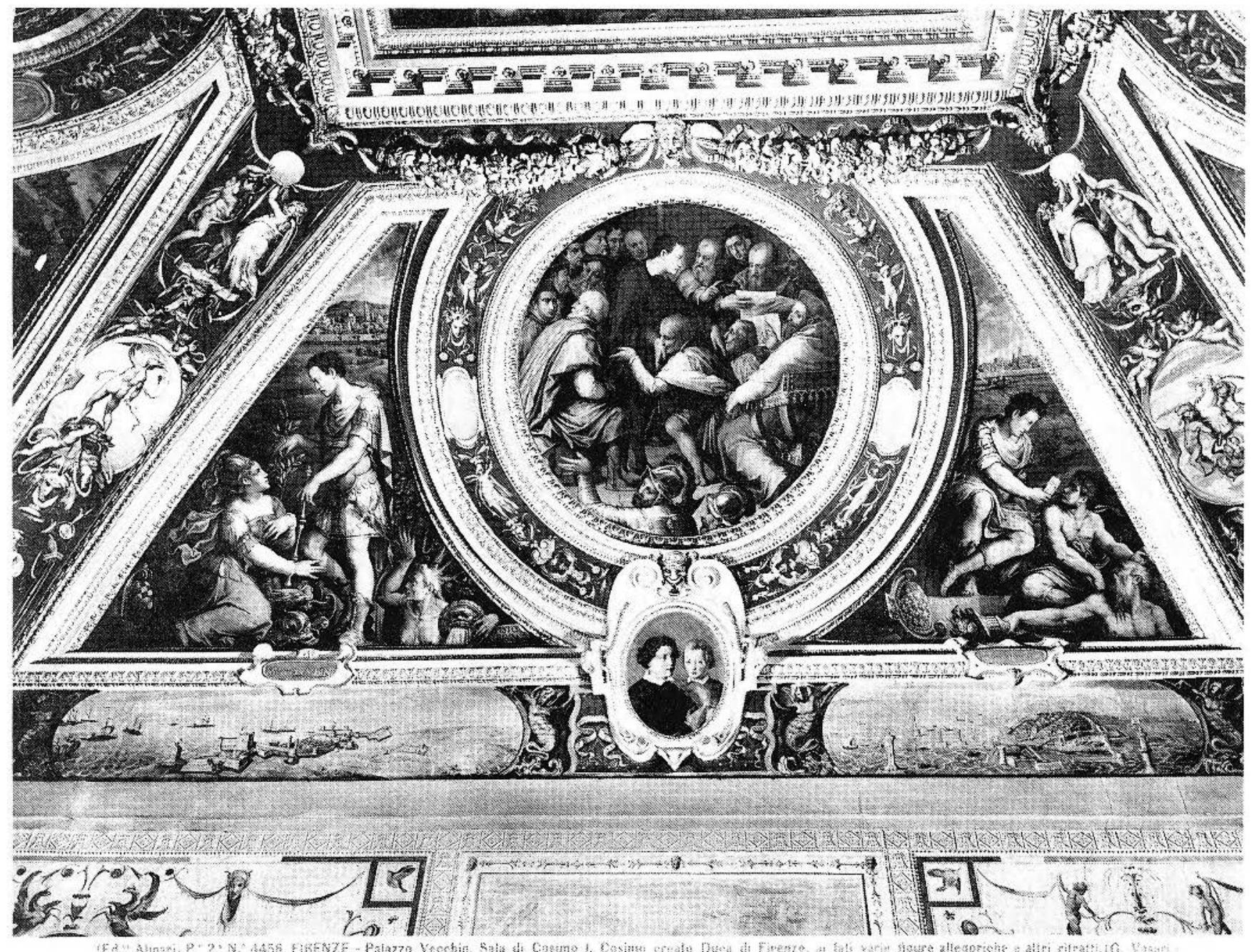

of Athens towards the end of July 1343! Traballesi's state treasurer accompanies a ruler who can only be identified in this context as King Acrisius-Jacopo V d'Appiano, Signore of Piombino. Cosimo holds a purse as state treasurer and looks down, ever so sternly, on the greedy Signore of Piombino because his coffers are literally being drained in order to defend the territory of his impotent uncle. Moreover, by situating the two walls being constructed to either side of Danaë's tower parallel to the picture plane, Traballesi demonstrated that the narrative takes place within the "handsome quadrilateral, bastioned fortification" constructed around Piombino by Giovambattista Camerini from ca. 1543-45, on order of Duke Cosimo I (compare bottom left of fig. 11). ${ }^{49}$ Thus, according to Borghini's iconographical tour-de-force, precisely two hundred years separate two of the historical events conflated with the myth of Danaë in the foreground of Traballesi's painting.

Since Traballesi's foreground contains a conflated
Piombino and Florence, in addition to Danaë's tower of the Bargello-Palazzo della Signoria, then one would expect the background to represent the island of Elba, at least in part. This line of reasoning is reinforced by Vasari's fresco of Cosimo I and the Fortification of Elba in the Sala di Cosimo I, a plateau composition in which the duke and his associates are clearly standing on Piombino, looking down and across to the island of Elba (fig. 12). History contributes to this assumption as well. First, when Francesco was born, his father was deeply embroiled in the politics surrounding Piombino, politics that necessarily included the nearby island of Elba. Secondly, Elba had been an important site of ferrous mines since antiquity. ${ }^{50}$ The very nature of the island therefore agrees with the fundamental concetto for Cosimo's east wall concerning mining the earth's riches (and with the action in Casini's adjacent Forge of Vulcan). Thirdly, Elba was the mythological refuge for Jason and his Argonauts at the time of the Trojan war (the primary con- 
Figure 12. Giorgio Vasari and Giovanni Stradano, Cosimo I and the Fortification of Elba ca. 1556-59, Sala di Cosimo I, Palazzo della Signoria, Florence (Photo: Alinari/Art Resource, New York).

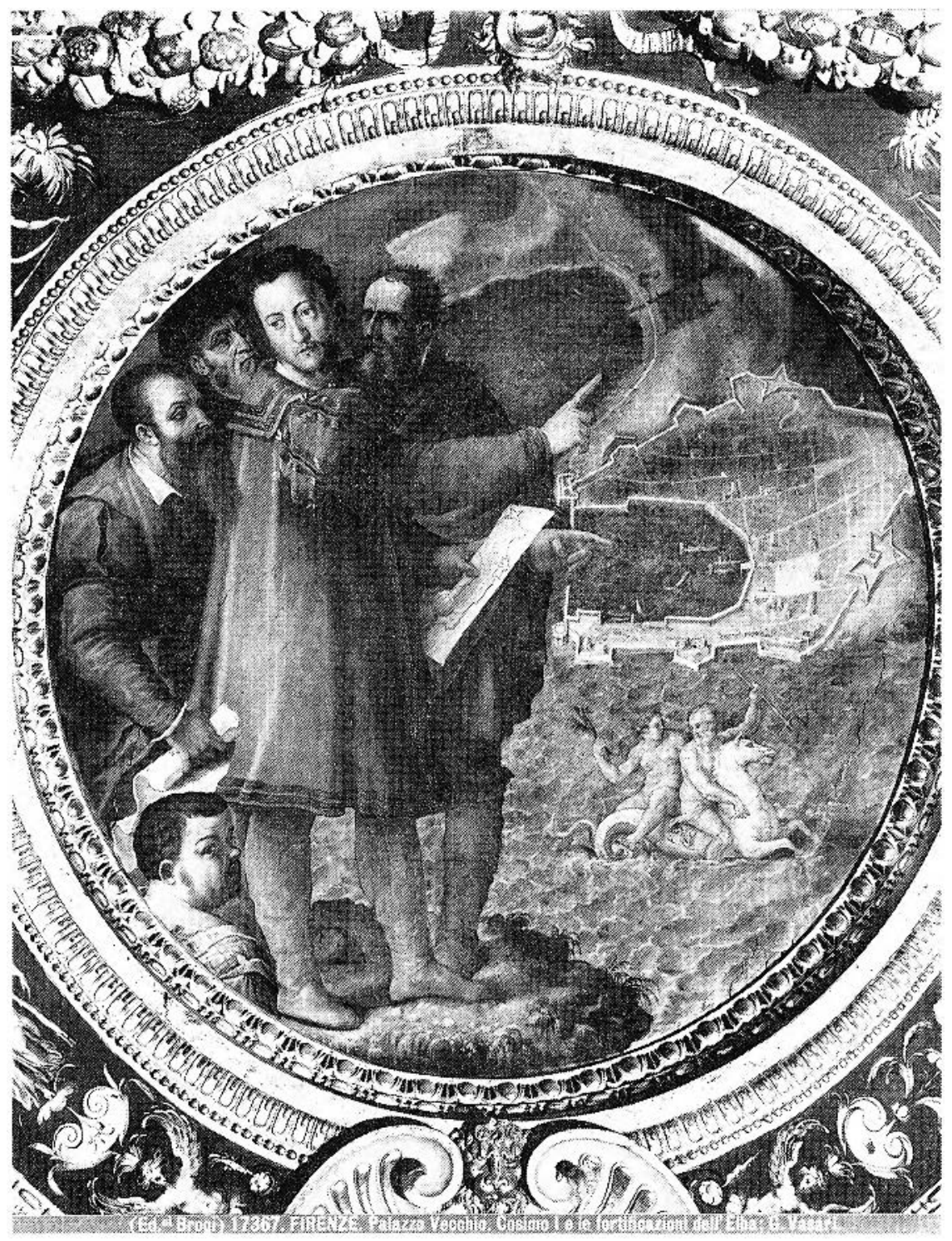

from Peru and the West Indies. For the mythology celebrating the Hapsburgs, Borghini opted for Perseus' rescue of Andromeda. Thus, by 1565 Borghini had already forged the analogues to Traballesi's Danaë-Fiorenza-Diana looking towards the "luminous" shower, and to the safekeeping of the Tuscan state, notably by the Hapsburgs. ${ }^{53}$ The Medici dominion was celebrated by the island of Elba, personified as a warrior accompanied by putti playing with Cosimo's dolphin and anchor of the festina lente impresa, and by the Order of the Golden Fleece, with Jason and his Argonauts, and Jason and Medea raising an altar to Jove on the Elban shore. Hence, by 1565 Borghini had already devised the nexus uniting Traballesi's Rain of Gold and Marsili's Atalanta and Hippomenes. Indeed, as I shall demonstrate, he had already determined the concetto for Traballesi's Rain of Gold, and for the entire eastern end of the Scrittoio.

Schaefer has argued that Jacopo Zucchi's Gold Miners, the centre-piece of the earth wall's upper register, takes place in Cerro de Potosì, Peru. ${ }^{54} \mathrm{He}$ has identified the well-dressed men and women in the background as a Spanish inspection party led by Francesco I's cousin Don Francesco de Toledo y Figueroa. Further, he has found that this event took place in November

text of Casini's Forge of Vulcan). ${ }^{51}$ The island therefore carries a meaning that is wholly consonant with Danaë's "missing" chain of the Order of the Golden Fleece.

Further evidence pointing in the direction of Elba is contained in Borghini's earlier union of pagan myth and contemporaneous politics at the Ponte a Santa Trinità, as part of the apparato created in honour of the marriage of Francesco I and Giovanna of Austria in $1565 . .^{52}$ In order to celebrate the houses of the bride and groom, Borghini dedicated two grisaille narratives to each of the Hapsburgs and the Medici. One featured an historical event and the other, a mythological one. The protective Christian rule of the Hapsburgs in the New World was the subject of one historical grisaille. It featured a nymph looking towards Christ within a luminous cross together with birds and animals
1569, on order of Giovanna's cousin, King Philip II of Spain. Thus, as Schaefer recognized, Borghini drew on the apparato at the Ponte a Santa Trinità for the main wall of the Scrittoio, apparently updating his precedent with a virtually contemporaneous event.

In keeping with his general method, Borghini provided a mythological foil for Zucchi's Gold Miners in Andrea del Minga's Deucalion and Pyrrha, the central sportello painting flanked by the Rain of Gold and Atalanta and Hippomenes (fig. 13). By evidently instructing del Minga to provide Pyrrha with a jewel-encrusted crown, red hair parted in the middle, and a distinctly Hapsburg chin, Borghini continued his method of conflating mythology and history, for Pyrrha is clearly an idealized portrait of Giovanna of Austria (fig. 14). Borghini's method differed for the lateral 
Figure 13. Andrea del Minga, Deucalion and Pyrrha, ca. 1571, Scrittoio of Francesco I, Palazzo della Signoria, Florence (Photo: G. F. S. G., Florence).

pendants on the eastern wall (and indeed for all corners of the Scrittoio) due to the presence of a bronze deity in lieu of a narrative with contemporaneous import located above the sportello. Still, he maintained his design by instructing Traballesi and Marsili to render portrait-likenesses of contemporaneous figures in their paintings. He also had the artists render cityscapes based on actual sites, in keeping with the conflated BargelloPalazzo della Signoria that houses Danaë-Fiorenza-Diana and that signals the re-location of the myth of Danaë from Argos to Florence. As I shall now endeavour to demonstrate, though not without some trepidation, the city-and seascapes in the background of the Rain of Gold are accretions of different locales based on one predominant site; they partake of the same methodology whereby $\mathrm{Pi}$ ombino's "handsome quadrilateral, bastioned fortification" hosts the Florentine Bargello-Palazzo della Signoria: "EX MVLTIS VNVM."

Traballesi's mountainous backdrop bears a distinct resemblance to the Elban shoreline, especially when viewed from the sea en route from Piombino to Portoferraio, the island's main port. The round structure located at the tip of the narrow landmass jutting into the water, to the right of

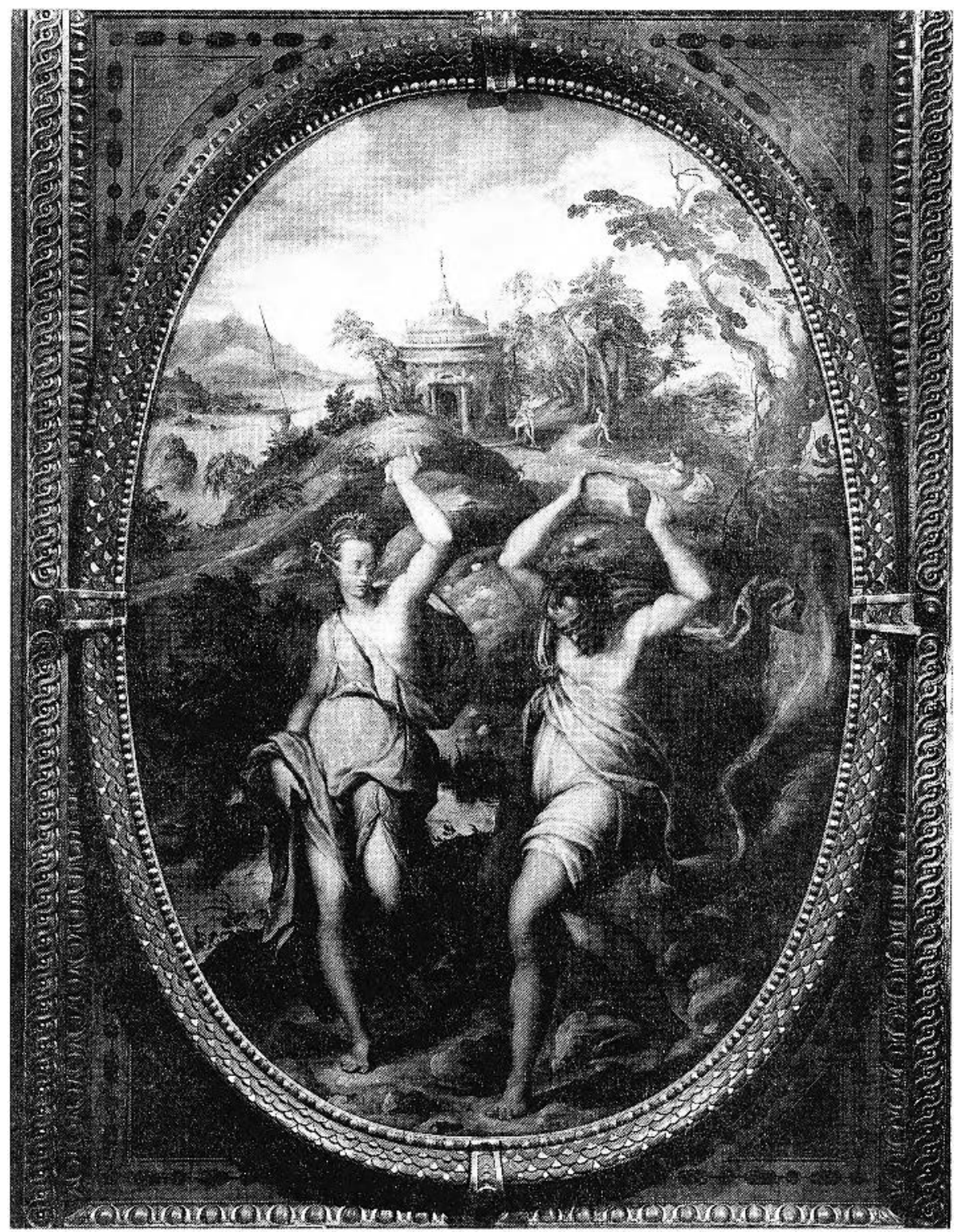
Danae's tower, looks like the tower that the Pisans erected at Marciana Marina in the twelfth century, known as the "torre saracina." 55 Marciana Marina is located at the western part of the island. The cityscape located to the left of Danaë's tower also evokes Elban topography, especially given the steep terrain, winding roads and water at its base. With Marciana Marina evidently located in the distant west, this cityscape ought to be located at the island's eastern end. It could represent the mining district of Rio dell'Elba, rented by Cosimo I in 1542, or more likely the elevated town of Capoliveri, also located in eastern Elba. ${ }^{56}$ At the same time, the steep incline, winding roads and prominent city gate, not to mention the figures spotted here and there, call to mind Ambrogio Lorenzetti's famous fresco of the Peaceful Sienese City and
Countryside in the Palazzo Pubblico of Siena. Whereas the outline of Traballesi's city does not actually correspond to the Sienese skyline, there is no question that the distinctive lantern, dome and drum crowning the centre of the city belong to the Sienese Duomo (fig. 15). It would appear, then, that in the Rain of Gold eastern Elba hosts the ordinarily landlocked, but still eastern Tuscan city of Siena.

Given that Marciana Marina is located to the west, and Rio dell'Elba/Capoliveri-cum-Siena to the east, then the landmass situated to the right of Danaë's tower should logically represent Portoferraio. However, instead of a recognizable Portoferraio, one finds an exceedingly odd little island connected to the mainland by way of a man-made bridge. If anything, the strange conglomeration of decid- 
Figure 14. Alessandro Allori, Giovanna of Austria, ca. 1568, Museo degli Argenti, Palazzo Pitti, Florence (Photo: G. F. S. G., Florence).

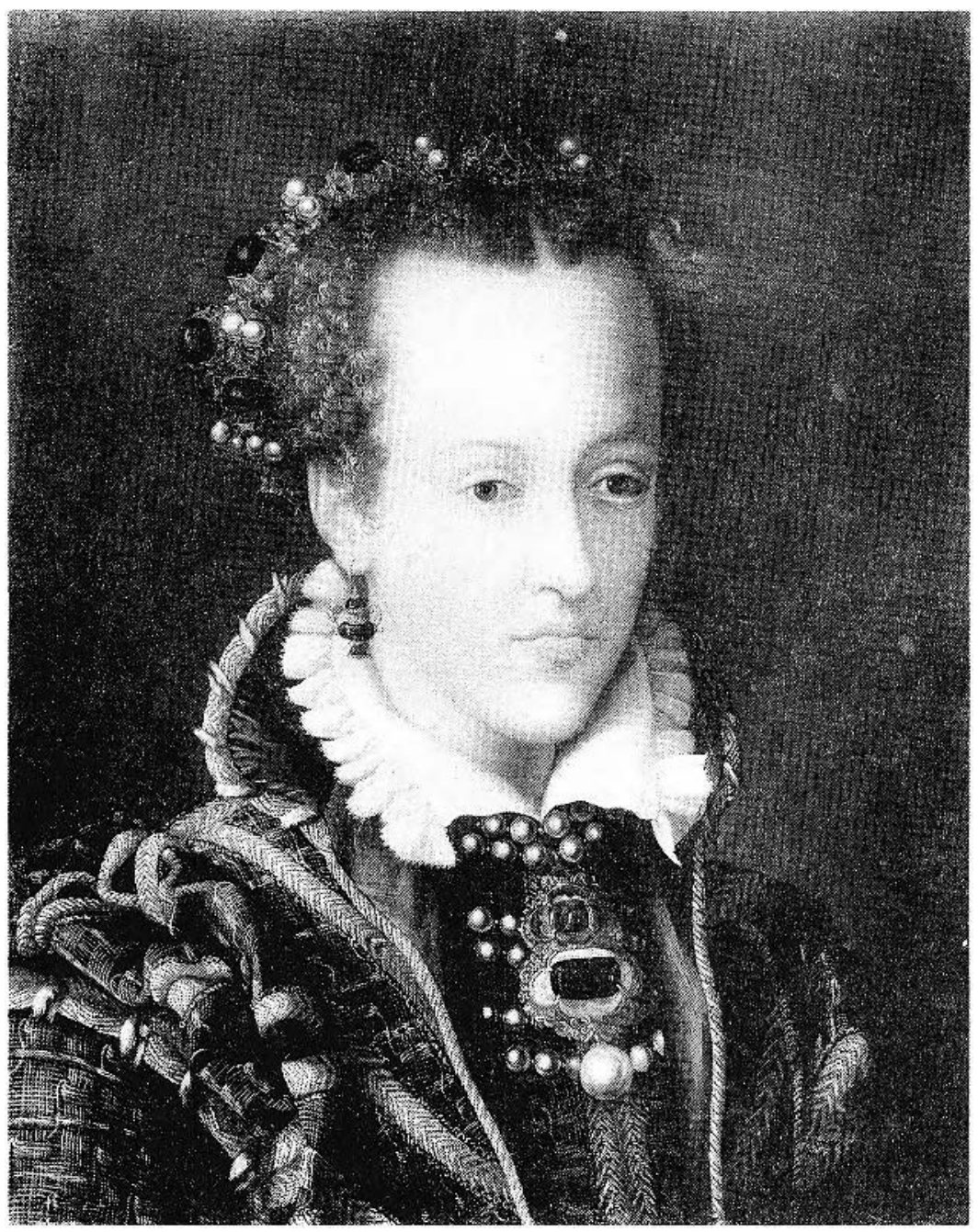

anship into relief. In addition, both the soldier's presence and his sword and shield are likely surrogates for Danaë's missing military attributes, the helmet and arrows. Since the lunette tondo features an armoured Cosimo I, then it would appear as though the duke above and the soldier taking part in the myth of Danaë below are somehow linked according to Borghini's "marvellous chain of nature." 58 Indeed, I would argue that the soldier functions in the same manner as Cosimostate treasurer, who acts out the myth as a member of King Acrisius' entourage (as the Medici regularly reenacted the voyage and adoration of the Magi - a tradition clearly evoked in Marsili's pendant painting). But the myth is silent concerning the soldier's manifestly important gesture. Just as one must identify Cosimo's portrait and understand the historical context in which he lived in order to understand the politics of Borghini's poetic conceit, so one must look to history in order to explain why the soldier is keeping the bearded figure in Acrisius' entourage in his place. Above all, one must attempt to identify this elderly, bearded gentleman.

The figure being held in check by the soldier is dressed in a flowing brown robe. Thus, he is dressed in the manner of the state treasurer, though his status evidently calls for less flamboyant garb. Also like Cosimo in his

edly a-classical structures on this island bears a certain resemblance to the Hungarian fortress depicted by Giovanni Stradano in the Sala di Clemente VII (fig. 16). Just as Siena is rather farther from the water than the Rain of Gold would have one believe, so this Hungarian fortress is actually located on land, notwithstanding its enclosing moat. ${ }^{57}$ In order to make sense of these identifications, it is best to return to the foreground of the Rain of Gold, for, as I have been endeavouring to demonstrate, each and every component in the foreground of this painting directs the viewer to the historical events that Borghini likened to Danaë's golden rain.

The soldier standing before Acrisius' entourage, holding a sword and an orange object that I would identify tentatively as a shield, is a curious addition. In a general sense, he may be understood as a synecdochic marker for the guards posted around Danaë's prison. Thus, his presence accords with the myth insofar as it puts the theme of guardirole as state treasurer, this gentleman's feet are bare so that he may commune directly with the earth, the fundamental subject of the eastern wall. By providing these two figures in Acrisius' entourage with visual similarities, Traballesi indicated that they share a certain bond. In order to determine the nature of this bond, it seems reasonable to return to the Sala di Cosimo I, for Bartoli - and Vasari and Stradano - took care to include portrait likenesses of the most significant personages in Duke Cosimo I's life in the frescoes celebrating his achievements. ${ }^{59}$ Granted, the identification of portraits (like the identification of Traballesi's cityscapes) is a tricky and perilous business, and one must proceed with caution. Having said this, I suggest that Traballesi gave his elderly gentleman the features of Ottaviano de'Medici. Ottaviano is depicted twice in the Sala di Cosimo I: once directly beside Cosimo I on his election as Duke Alessandro de'Medici's successor as "Primary head of the city of Florence and of her dominion" (fig. 11), and 
Figure 15. Panorama of the city of Siena (Photo: Alinari/Art Resource, New York).

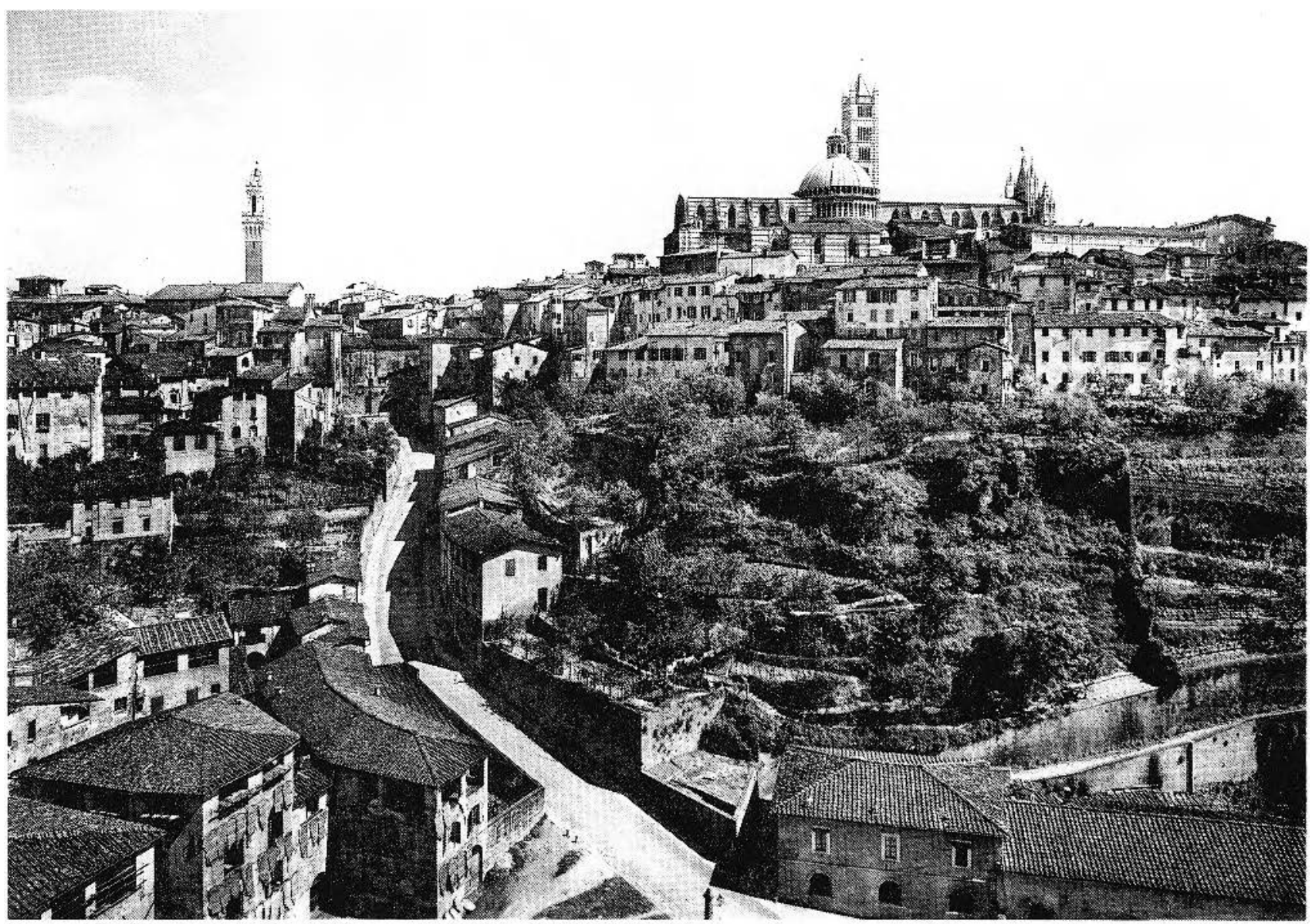

once in the Triumph of Cosimo I at Montemurlo, separated from the irate duke by the helmeted Pirro Colonna da Stipicciano (fig. 10) - as another, clearly contemporaneous figure separates him from the irate duke-state treasurer in Traballesi's Rain of Gold. ${ }^{60}$

The son of Lorenzo di Bernardetto de'Medici, Ottaviano is usually remembered as an avid art collector and friend of both Michelangelo and Vasari. ${ }^{61}$ In the 1520s he was the guardian of Ippolito and Alessandro de'Medici at Poggio a Caiano. With the seige of Florence in 1529, Ottaviano was naturally imprisoned with other Medicean supporters. ${ }^{62}$ When the Republic fell in 1530, thanks in large part to Pope Clement VII and the Emperor Charles V, he was freed from prison and elected to the Magistrato Straordinario, the group of twelve citizens charged with the reorganization of Florentine government. In 1531, Ottaviano was elected Gonfaloniere di Giustizia. The following year, he took part in the further obliteration of vestiges of republican government, instigated by Clement VII. Further, he was one of the first citizens nominated for the Florentine Senate and acted as Duke Alessandro's confidant throughout his brief reign. In 1537, Ottaviano proved to be one of Cosimo's most ardent supporters in the deliberations concerning the successor to the murdered Duke Alessandro. Thereafter, he became Cosimo's confidant, and Depositario Generale, though the duke was not without certain reservations concerning Ottaviano's honesty - reservations that were quashed by Ottaviano's artist friends. In addition to overseeing Cosimo's financial affairs, Ottaviano was married to Francesca di Jacopo Salviati. Like Jacopo V, then, Ottaviano was Cosimo's uncle. He died in May 1546, the necessary terminus ante quem for the action involving the soldier in Traballesi's Rain of Gold.

As far as I am able to determine, Ottaviano de'Medici did not figure in the politics surrounding Piombino and Jacopo V-Acrisius. Needless to say, he also post-dated the Duke of Athens-Acrisius by two centuries. To complicate matters even more, in Traballesi's Rain of Gold he stands before a figure, wearing a white collar and dark suit, who is unquestionably Cosimo's second son Ferdinando I de'Medici, born in 1549 (compare the portrait of Ferdinando, located beside Cosimo, in my fig. 18). Ottaviano and the soldier therefore frame a figure who had not even been thought of at the time of Ottaviano's death! Ferd- 
Figure 16. Giovanni Stradano, Ippolito de'Medici arriving in Hungary, ca. 1556-62, Sala di Clemente VII, Palazzo della Signoria, Florence (Photo: Alinari/Art Resource, New York).

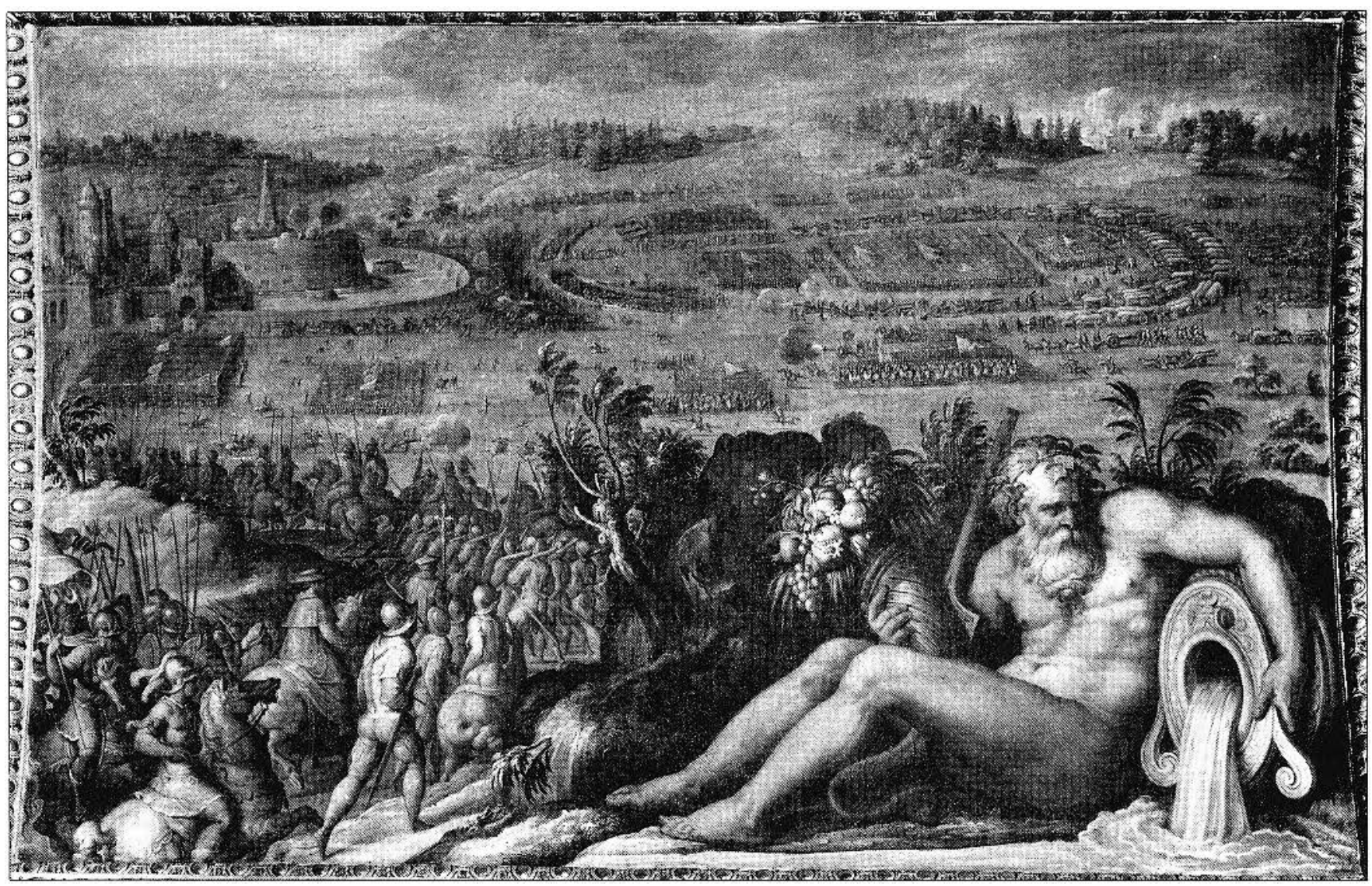

inando I's teen-aged presence necessarily moves the action of the Rain of Gold forward, at least to the 1560s. Borghini's plot thickens, to say the very least.

Since the soldier holds Ottaviano back before the Duke of Athens' "other" bulwark, then one may reasonably conclude that such action is contrary to the well-being of Florence, not to mention Piombino. Accordingly, the soldier's gesture ought to refer to Ottaviano's imprisonment in 1529. In the larger sense, Ottaviano's presence ought to concern the republicanism of 1527-30. Danaë-Fiorenza-Diana's location on Traballesi's balcony reinforces this reading, as it reflects the position of the republican inscription above the portal of the Palazzo della Signoria celebrating Christ and the Virgin as the King and Queen of Florence. Thanks to the rain of gold, Danaë's position also signals the emancipation of Ottaviano and the city of Florence (and Piombino) from anti-Medicean rule. As such, the decrepit King Acrisius stands for the republican usurpers of Florentine liberty during the end of the third and beginning of the fourth decades of the sixteenth century. Danaë and her golden rain could then embody the Medicean dukes Alessandro, Cosimo and Francesco, as they all adopted Perseus as their alter ego. ${ }^{63}$ But since the first Grand Duke of Tuscany is the alter Jove, then Danaë's son is necessarily Francesco I. Given Ottaviano's manifest presence, then in this context Perseus is first and foremost Duke Alessandro de'Medici. Thus, by instructing Traballesi to include the portrait likeness of Ottaviano de'Medici within Acrisius' entourage, Borghini was able to signal yet a third historical period in which Florence was imprisoned, like Danaë in her tower, and then saved through the grace of God. I shall return to Ferdinando I in due course.

During the republican years of 1527-30, there was but one hope for Florence's liberation: Alessandro de'Medici. As Ottaviano de'Medici was being incarcerated, the Medici Pope Clement VII was completing negotiations with Charles $\mathrm{V}$ for the Treaty of Barcelona, whereby Alessandro and his Medicean heirs would be given control of the republic of Florence in perpetuity. As part of the bargain, Clement VII promised to crown Charles V Holy Roman Emperor, a promise fulfilled on 4 February 1530 in Bologna and commemorated for all time in the central ceiling fresco of the Sala di Clemente VII, as in Baccio Bandinelli's Udienza, the grandiose monument to the Medicean dynasty that Ammannati's Fountain of Juno was to face in the Sala Grande. ${ }^{64}$ Alessandro rode into Florence accompanied by 
Figure 17. Giovanni Stradano, Alessandro de'Medici entering Florence through the Porta a San Gallo, ca. 1556-62, Sala di Clemente VII, Palazzo della Signoria, Florence (Photo: Alinari/Art Resource, New York).

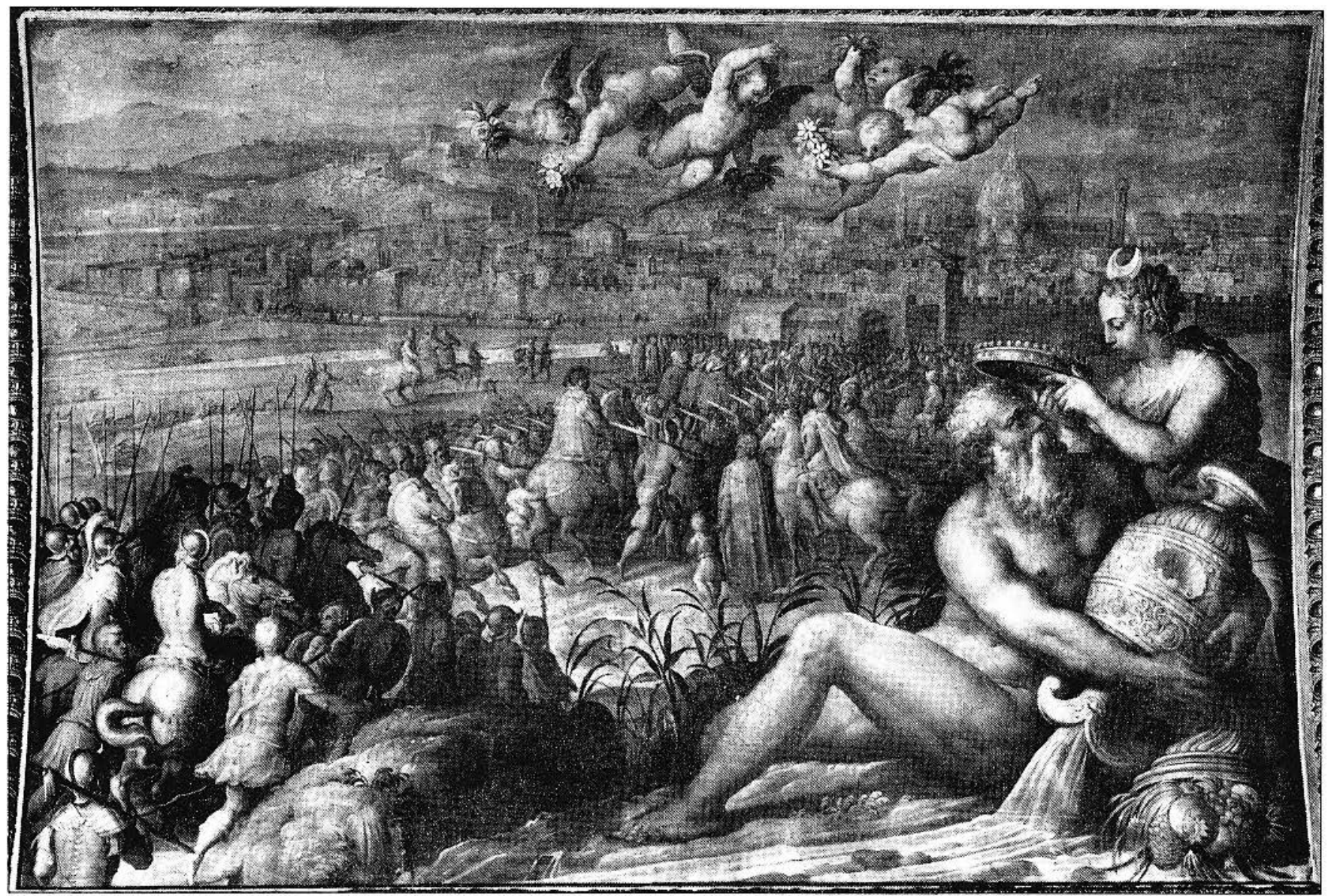

imperial troops in order to take up his new position in 1531. In the Sala di Clemente VII, Stradano demonstrates that as Alessandro entered Florence, Fiorenza-Diana was crowning the abundant Arno River with the ducal crown, and airborne putti were strewing flowers in honour of the occasion (fig. 17). The following year, Ippolito rode into Hungary accompanied by the papal army in order to assist Charles $\mathrm{V}$ in his campaign against the Turks. As he was entering Hungary, the ivy-crowned Danube River was insuring a copious supply of health-giving and navigable waters (fig. 16).

Much as Alessandro and Ippolito emerged victorious against inimical republicans and Turks thanks to imperial backing, so Traballesi's Rain of Gold pits a garrisoned Florence against Walter of Brienne and anti-Medicean republicans, and a garrisoned Piombino against Jacopo V-Acrisius and the treacherous Turk. If Traballesi transformed the island of Portoferraio in to a Hungarian fortress, now located in the water, then he surely did so in order to evoke the Perseus capable of walking on water, Duke Alessandro de'Medici, as well as the Perseus about to be baptized with the assistance of the Queen of Hungary's legate, Francesco
I. ${ }^{65}$ Nor was Ippolito de'Medici altogether forgotten. Since Ferdinando I became a cardinal in 1563, his placement beside Ottaviano recalls this "other" Medicean cardinal, whose presence is implicit in the fortified Hungarian Portoferraio. To continue the analogy, as the Arno River, Fiorenza-Diana and flower-strewing putti in Alessandro entering Florence through the Porta a San Gallo call to mind Traballesi's Danaë-Fiorenza-Diana, so the Danube River crowned with bacchic ivy in Cardinal Ippolito arriving in Hungary evokes the Holy Roman Emperor Charles V. At this point, one cannot help but recall Ovid's rendition of the myth of Danaë:

There was one only, Acrisius, the son of Abas ... who forbade the entrance of Bacchus within the walls of his city, Argos, who violently opposed the god, and did not admit that he was the son of Jove. Nor did he admit that Perseus was son of Jove, whom Danaë had conceived of a golden shower. And yet, such is the power of truch. Acrisius in the end was sorry that he had repulsed the god and had not acknowledged his grandson. The one had now been received to a place in heaven; but the other, bearing the wonderful spoil of the snake-haired 
monster, was taking his way through the thin air on whirring wings. ${ }^{66}$

As Charles V's troops were sacking Rome in 1527, the anti-Medicean republicans seized the opportunity to take over Florence. By 1530, they were fighting to block "the entrance of Bacchus within the walls of his city," albeit to no avail. In 1531 Charles V's Landsknechte enabled Alessandro to ride into Florence and to begin his rule as the first in the everlasting line of Medicean dukes. A decade later, yet another hostile force was "violently oppos[ing] the god," for Jacopo V was as much a bane to Charles V as to Cosimo I. In refusing to lend a hand with the defense of his state, Jacopo $\mathrm{V}$ was not only draining Cosimo's purse, but he was also exasperating Charles V, so much so that the emperor made the duke's most ardent wish come true by giving him sovereignty over Piombino. But I am putting the cart before Cosimo's horse. By 1570, finally, Charles V had "been received to a place in heaven," while "the other, bearing the wonderful spoil of the snake-haired monster," had grown into the mature Francesco I, celebrated in Vasari's Creation of Coral on the Scrittoio's water wall.

Throughout the numerous sixteenth-century events that Borghini conflated with the myth of Danaë (and I have not finished exploring the possibilities), there remains one constant: the Holy Roman Emperor. As Traballesi's "Hungarian" fortress-cum-Portoferraio would suggest, Borghini viewed Charles V as the alter Bacchus described by Ovid and "worshipped" by the Medicean dukes of Tuscany. The cityscape located to the left of the Bargello-Palazzo della Signoria would seem to reinforce this reading. I have suggested, perhaps ingenuously, that this cityscape in part reflects the Elban town of Capoliveri. Well, it so happens that the very name Capoliveri is derived from the Latin Caput Liberi, meaning the peak consecrated to Liber, otherwise known as Bacchus! ${ }^{67}$ This etymology is striking in the context of Traballesi's Rain of Gold for it situates Cosimo I's rule squarely within the realm of the Bacchic Emperor Charles V, hence reflecting the actual political situation in which Cosimo oversaw his Tuscan state. If the right-hand side of Traballesi's composition concerns the successful defense of the fortified state, by twelfth-century Pisans as by sixteenth-century Florentines (and Piombinese), then the left-hand side surely concerns the God-given gift of perpetual Medicean rule. What is more, Borghini injected these themes into the highly significant vertical axis of Traballesi's painting, comprised of Danaë, the golden rain and the Bargello-Palazzo della Signoria. As the reader has no doubt recognized, he found a potent precedent for such organization in the Expulsion of the Duke of Athens (fig. 5).
It can hardly be coincidental that the "Hungarian" island-cum-Portoferraio occupies the same space in Traballesi's painting as the Duke of Athens in Orcagna's, for both concern the extirpation of inimical forces. As such, one would expect the left-hand side of Traballesi's painting to bear some relationship to the left-hand side of Orcagna's. When one recognizes that Capoliveri-Siena occupies the same space as St Anne in the Expulsion of the Duke of Athens, then one ought to think in terms of Giovanna, Charles V's niece and Francesco I's wife. First, this analogy agrees with Borghini's fascination, nay obsession, with etymology and double entendre, strongly evident in his notebooks housed in the National Library of Florence, as in his apparent choice of Capoliveri. Secondly, it complements what I shall call the biographical symbolism pervading the eastern wall: Giovanna is portrayed in del Minga's sportello painting as Pyrtha, the mother of Francesco-Deucalion's earthen progeny, and she is portrayed in Marsili's painting as Atalanta, Francesco-Hippomenes' wife. In such a context, the Rain of Gold most certainly concerns the very real Medicean wish that Danaë-Giovanna of Austria give birth to a Medicean Perseus, a male heir to rule the realm of his exalted forebears, and a brother to Anna, no less, born on 31 December 1569 , only months before Borghini began to pen his programme for Francesco I's Scrittoio.

But what of Siena, and the as yet unidentified figures in Acrisius', or better still, Cosimo's entourage, above all the manifestly significant figure positioned between the duke and his confidant? Although Francesco I is the obvious candidate, given Cosimo and Ferdinando's presence, this figure does not really resemble the prince regent: his beard is too full, his face not terribly sallow, and his eyes not sufficiently piercing (compare Francesco's portrait at the right of fig. 18). I must now throw caution to the wind - again - and suggest that Traballesi gave this figure the features of Giulio di Alessandro de'Medici, the illegitimate son of the first Duke of Florence. Visual evidence is meagre. To my knowledge, the only extant portrait of a bearded and relatively youthful Giulio was created in the eighteenth century for a book treating the Medici family. ${ }^{68}$ While Traballesi's figure certainly resembles this representation of Giulio, such evidence is not terribly convincing in and of itself. It becomes more convincing on considering the life of Giulio and the context of Traballesi's Rain of Gold, especially vis-à-vis the Sala di Clemente VII.

Giulio d'Alessandro de'Medici was born ca. 1533, the result of one of his father's many Jovean liaisons. ${ }^{69}$ Taddea Malespina, a wealthy patrician, was likely his mother. On the death of his father, Giulio was all of about four years old. Notwithstanding, Clement VII planned to install him 
Figure 18. Giovanni Butteri, attr., St Anne Altarpiece, 1575, Gallerie degli Uffizi, Florence (Photo: Alinari/Art Resource, New York).

as Alessandro's successor. Thanks in large part to Ottaviano de'Medici's powers of persuasion, the majority of senators voted in favour of Cosimo, proclaiming him "Primary head of the city of Florence and of her dominion" Cosimo I then took Giulio under his wing. Now, according to Charles V's dictates, Giulio was in point of fact the rightful heir to his father's estate. Cardinal Cybo, the boy's former guardian and tutor, was exceedingly vocal on this point, so much so that the emperor had to arbitrate. It was at this time that Charles V gave Cosimo the title of Duke of Florence. With his position thus secured, Cosimo sent Giulio to Pisa, where he received an education and lived in a manner befitting a duke's son. In 1562, when he was around thirty years old, Giulio became the first Cavaliere in the Order of the Cavaliers of St Stephen. This Order was founded by Cosimo I, with the blessing of Pope Pius $\mathrm{V}$, on the anniversary of his victory over the Sienese at Marciana in Val di Chiana (as opposed to Marciana Marina!). ${ }^{70}$ The essential mandate of this maritime knightly religious Order was to insure peaceful waterways which, in 1562, meant eradicating the Turkish threat. The symbol of this Order was a red cross on a white ground, like the republican cross placed above the portal of the Palazzo della Signoria. In 1563, Giulio was elected to the post of Ammiraglio, commander of the Or-

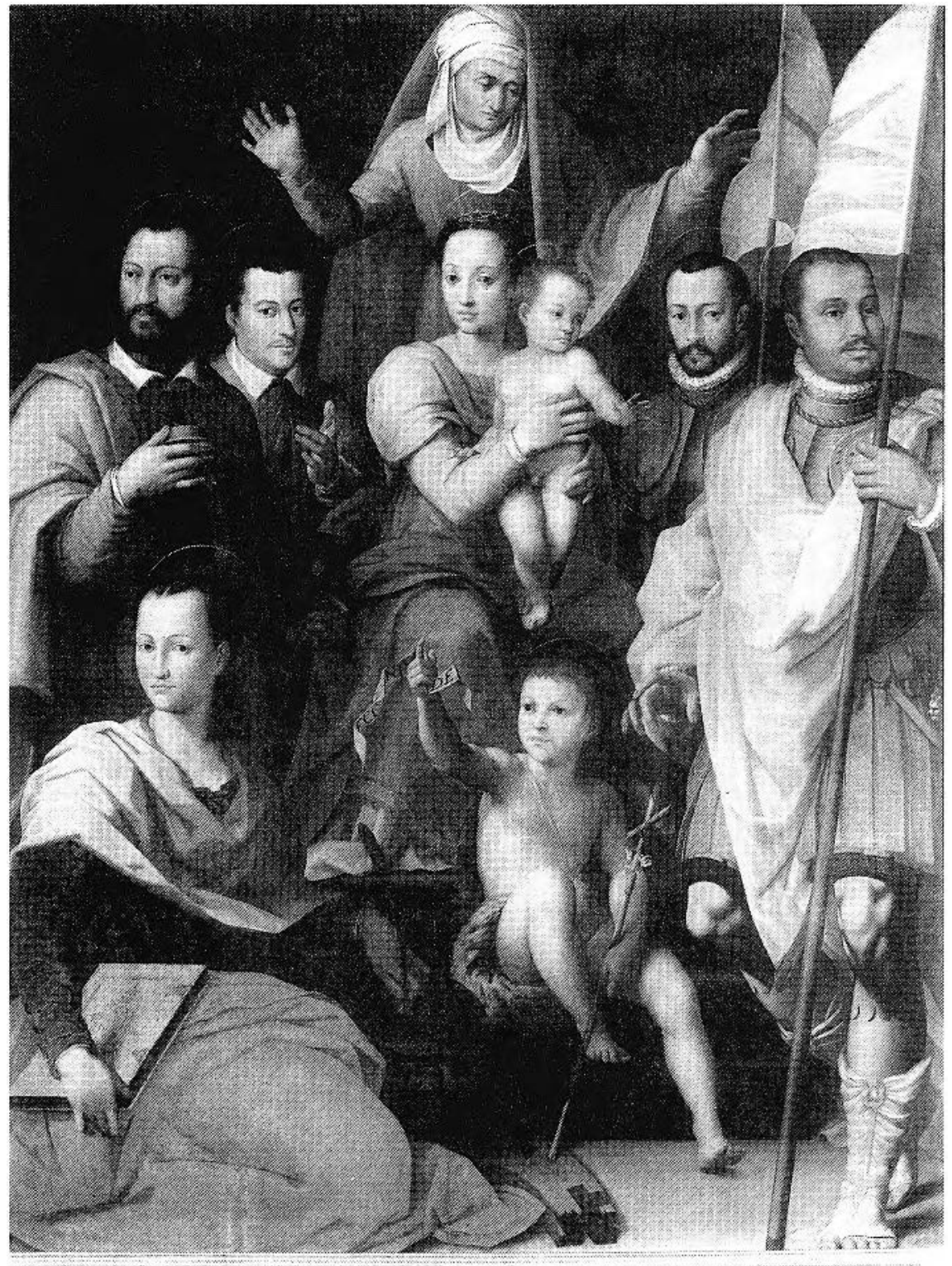

der's fleet, and accompanied Francesco I on his trip to Spain in this capacity. Three years later, he was elevated to the even more prestigious post of Gran Contestabile. By 1569 Giulio had proven himself to the extent that he travelled to Rome with Cosimo I to attend the ceremony in which Pius $\mathrm{V}$ crowned his step-father the first Grand Duke of Tuscany.

I have argued that Ottaviano de'Medici is included in the Rain of Gold owing to his role as guardian. His collocation with the soldier actually enunciates this role: the guard in malo stands before the guard in bono, just as the right side of the painting (located to the sinister side of the Bargello-Palazzo della Signoria) symbolizes the defense of the realm (Bargello) and the left, its safekeeping (Palazzo

della Signoria). This symbolism of guardianship is perfectly consonant with the fundamental theme of the myth of Danaë. I have also argued that Ottaviano evokes Duke Alessandro de'Medici-Perseus, symbolically located on Traballesi's all-important vertical axis, as well as Cardinal Ippolito de'Medici, symbolically located both on a Hungarian Portoferraio and to the right of Ottaviano in the person of Ferdinando I. Since the vertical axis contains the themes of the left and right sides of the painting, then it is sensible that Alessandro's presence be signalled on the left side of the composition. Could Borghini have chosen a better surrogate than Alessandro's own son Giulio?

According to the organization of the Rain of Gold, 
Giulio ought to bear a relationship to Cosimo as well as to Ottaviano, given his position between the two. Indeed he does, since Cosimo acted as Giulio's guardian, from his youth through his maturity. Since Traballesi clearly depicted Giulio during his mature years, ca. 1560, he was thus honouring Alessandro's son as the first Cavalier of the Order of the Cavaliers of St Stephen. Given that the Order was founded on 2 August, at once the anniversary of Cosimo's defeat of the Sienese at Marciana and St Stephen's feast day, then Giulio's presence provides a raison d'être for the Sienese Duomo. It is no doubt for this reason that Traballesi elevated the lantern and dome above the city of Capoliveri-Siena, as he elevated Giulio's own head ever so slightly above those of his companions. Further, Giulio's presence as the Cavalier of the Order of the Cavaliers of St Stephen does much to explain why a forty-year-old Cosimo is decked out in equestrian armour in the earth wall's crowning tondo portrait. When one further considers that Cosimo minted coins in honour of his Order, known as soldi, and displaying the Medici stemma and the Order's Cross, then it is but a short step from Cosimo's tondo portrait to the golden rain in Traballesi's Rain of Gold. ${ }^{71}$ In fact, since a mere day separated the anniversary of Cosimo's victory at Marciana and the foundation of the Order of the Cavaliers of St Stephen (2 August) from Cosimo's victory at Montemurlo and Francesco's Baptism, not to mention the Emperor Augustus' victory at Actium (1 August), Medicean panegyrists saw fit to overlook a mere twenty-four hours. ${ }^{72}$ Thus, the lantern and dome of the Sienese duomo, Giulio and the tondo Cosimo each rise to the occasion celebrated in the Rain of Gold! Borghini was not only extremely well educated; he was also very, very witty. With the central figure's identity as Giulio thus established, one may conclude that Borghini had Traballesi create a united Medicean front behind King Acrisius, beginning with Cosimo I and continuing across the illusionistic space with Giulio, Ottaviano and Ferdinando I. History will further clarify the situation.

By 1545, an outraged Cosimo was trying to persuade Charles V to re-locate Jacopo V, and to give control of Elba to his Tuscan state so that he could defend it properly against foreigners, especially the French and the Turks. During this year, Perseus would slay his grandfather Acrisius; to paraphrase Riguccio Galluzzi, Jacopo V would finally die! $!^{73}$ The duke won a hand in this political game by reminding Charles $\mathrm{V}$ that he owed the Tuscan purse the considerable sum of 200,000 ducats. Accordingly, in 1547 Charles V gave Cosimo the go-ahead to build fortifications at Portoferraio (which the duke then renamed Cosmopolis) and to safeguard Piombino, albeit in the company of the emperor's Spanish garrison and governor. Cosimo sent Otto da Montauto with eight hundred infantrymen to Elba; he instructed Girolamo degli Albizzi to keep him posted on events in Piombino and Elba; he commissioned his architect to submit plans for the fortifications of Il Falcone, La Stella, and La Linguella; ${ }^{74}$ and he instructed his colonel Lucantonio Cuppano, who had charge of the army and who governed Portoferraio, to guard Piombino. Some of these personages may well constitute the remaining players in Traballesi's Rain of Gold. ${ }^{75}$

A decade later, on 3 July 1557, Cosimo received feudal investiture of Siena and Portoferraio. However, all was not as rosy as it might have appeared. While giving Cosimo the rule of Portoferraio with one hand, King Philip II of Spain, now acting as Charles V's successor, took away the duke's control of Piombino and Elba and the other islands with the other hand. ${ }^{76}$ It was a bitter-sweet victory, to be sure. Still, as J. R. Hale has pointed out, Cosimo's state may not have been "much larger than the one he found, but [it was] more powerful in terms of his unchallenged rule throughout it, its defensive strength, and the men and cash he could raise from it. ... what he gained would have been unthinkable in the early years of his rule." ${ }^{77}$ Indeed, as Vasari's explanation to Francesco I of his now lost fresco showing the return of Saturn and Ops during the reign of Jupiter indicates, Medicean panegyrists chose to dwell on the positive outcome of the decision:

This is none other than Charles V, who, moved by compassion for a troubled Italy, confirmed Duke Cosimo in his paternal home after the death of Duke Alessandro, and kept him at home by giving him the duchess, your [Francesco's] mother, as a wife so that his country could enjoy happiness. Seeing the duke's great strength, and wishing to increase the duke's domain, he made the island of Elba and the state of Siena come under the duke's rule. ${ }^{78}$

Since Cosimo I is depicted in the Scrittoio's eastern tondo as he looked and dressed ca. 1560, the Rain of Gold surely celebrates Cosimo's feudal investiture. Like Borghini's impresa "EX MVLTIS VNVM," it celebrates Cosimo's building of walls in the manner of an emperor and his rule of a now unified Tuscan state. Moreover, the Rain of Gold celebrates this investiture not by conflating Siena with Cosmopolis, the only remaining Medicean enclave on the island of Elba, but by placing the Sienese duomo on the skyline of Bacchus-Charles V's domain. In this way, the Rain of Gold partakes of the celebratory spirit once conveyed by Vasari's fresco of Saturn and Ops returning during Jupiter's reign. "EX MVLTIS VNVM," Traballesi's Rain of Gold quite literally represents the Medicean Age of Gold! 
Cosimo soon compensated for the lost hand of 1557 by founding a religious Order. ${ }^{79}$ As Master of the Order of the Cavaliers of St Stephen and Duke of Florence and $\mathrm{Si}$ ena, Cosimo I now exercised dominion over both the sacred and profane realms. It is surely for this reason that Cosimo-Jupiter takes on the persona of God the Father in Traballesi's Rain of Gold. In addition to founding his religious Order, in the early 1560s Cosimo also obtained the Emperor Ferdinand I's daughter Giovanna for his son Francesco. Enter Borghini, the apparato for the marriage festivities of 1565 and the Scrittoio of Francesco I. When Hippomenes-Francesco defeats Atalanta-Giovanna in Marsili's painting, King Schoenus-Cosimo I and his entourage adore the victor as the Magi had come to adore the Christ child (fig. 7). For Cosimo's political wishes for Medicean domination of the Tyrrhenian Sea now resided in the actions of his first-born son, Francesco I, baptized on the "anniversary" of the founding of the Order of the Cavaliers of St Stephen and a slew of victorious Mediceo-imperial battles.

In Marsili's painting, Hippomenes-Francesco receives the golden apples-cum-Medici palle that will ensure his victory over Acalanta-Giovanna from Venus-Fiorenza, DanaëFiorenza-Diana's foil and alter ego. Like father, like son; Francesco receives his palle, as Cosimo sports his red codpiece in the earth wall's crowning lunette and his soldi fall into Danaë's lap in the Rain of Gold! Moreover, Francesco receives this precious gift in a vignette strikingly reminiscent of Adam, Eve and the serpent in the garden of Eden. That Marsili positioned this vignette at the right side of his painting is no surprise, for as Orcagna's Expulsion of the Duke of Athens and Traballesi's Rain of Gold make clear, this is the defensive side in which evil "serpents," be they Turkish or anti-Medicean (that is to say, anti-Florentine), are extirpated from the paradise of the Tuscan Golden Age.

To the left of Marsili's composition, HippomenesFrancesco is transformed into a lion with his new bride Atalanta-Giovanna. Though verily a cruel punishment for having made love in Mother Nature's temple without giving Venus their thanks, in Borghini's rendition Ovidian blame is metamorphosed into Tuscan praise: Venus has transformed the ducal couple into Marzocchi, the lions of the city of Florence. ${ }^{80}$ Accordingly, they carry on the good government of their republican ancestors, descending to Augustus Caesar, Venus' own progeny and founder of the city of Florence. Much as Cosimo quite literally embodies Fiorenza in Traballesi's Rain of Gold, and Francesco, the trecento and cinquecento decoration above the portal of the Palazzo della Signoria, so in Atalanta and Hippomenes the leonine couple embody the very symbol of a free, republican Florence under Medicean control. ${ }^{81}$
But "Venus can do nothing without Bacchus," says the antique proverb; Venus could not help the Medici to rule their realm effectively without Bacchus at her side. ${ }^{82}$ She may have given Francesco-Hippomenes his golden palle, but how could he put them to good use without the god of merriment-cum-Charles V? Lest this Medici-Hapsburg union go awry, Borghini clearly instructed Marsili to draw on one of Francesco I's most recent and prized possessions: Michelangelo's Bacchus. ${ }^{83}$ Accordingly, Marsili transformed the master's sculpture into a fountain to the right of the tree bearing the golden apples, as a symbol of the fertility of the ducal couple-to-be. And Marsili surmounted the temple of Ops (or Themis in Ovid's rendition) with the sculptor's Bacchus to insure that the couple, about to rule as Marzocchi, forever enjoy Mother Nature's bounty. Though Charles V had "now been received to a place in heaven," Borghini insured that his memory would live on. As Bacchus surmounts Ops' temple, so Charles V is remembered for having paved the way for Grand Duke Cosimo I's progeny.

At the top of Marsili's composition, the foils to the impregnated Danaë-Fiorenza-Diana pull Ops' cart through the luminous sky, like the star that led the Magi to Bethlehem. Now working in Cosimo-Mother Nature's company, as indeed Francesco I was acting as prince regent, Hippomenes-Francesco and Atalanta-Giovanna lead their state even further beyond the borders established by the first Grand Duke of Tuscany. For beneath Ops' cart, deep into the illusionistic distance, Marsili depicted a fortified bastion that looks remarkably like La Stella, one of the three Elban fortifications constructed on Cosimo-Ops' orders in $1547 .{ }^{84}$ Nestled like a manger in Mother Nature's earth, La Stella is like the burst of light encircling Ops-Cosimo above, and like the leonine prince regent himself, the latest in the prodigiously long line of Medicean "lights." ${ }^{85}$ It is a beacon and God-given vehicle for the peace and prosperity that will be enjoyed on land and on sea once Francesco I takes hold of his father's helm.

Notes

This study was carried out with the assistance of a Vice-President Research Grant from the University of Western Ontario, in part during my first sabbatical, for which I am very grateful. I should also like to thank the University of Western Ontario for covering copyright fees for photographic reproduction. While in Florence, I was assisted by numerous people, too many to mention in this particular forum, alas. For now, I should like to extend tante grazie to Giuseppe Giliberto, Giovanna Lazzi, Mario Masserelli, Carlo Picchietri, Fiorenza Scalia and, above all, Franco Sottani. I also wish to thank Carol Doyon for graciously translating my abstract into French. 
1 Scott Schaefer, "The Studiolo of Francesco I de'Medici in the Palazzo Vecchio in Florence," Ph.D. diss., 2 vols, Bryn Mawr, 1976, I, 419-20. Prior to Schaefer, the only ostensible treatment of the Rain of Gold was penned by Luciano Berti, Il Principe dello Studiolo. Francesco I dei Medici e la fine del Rinascimento fiorentino (Florence, 1967), 72, who curiously focused on the artist, "il solitario gobbo Traballesi." Following Schaefer, Milori Wakakuwa, "Saggio sul tema iconologico dello Studiolo di Francesco de'Medici," in L'arte del rinascimento e la sua universalità, Atti del Simposio di studi Italo-Giapponese, 1-3 novembre 1980 (Tokyo, 1982), 201, addressed the alchemical ramifications of the myth, without actually analysing Traballesi's painting.

2 The literature on the Scrittoio is considerable, but that on its reconstruction, relatively meagre. See Marco Dezzi Bardeschi, "Del vecchio non c'è più et del nuovo non s'impara," in Lo Stanzino del Principe in Palazzo Vecchio. i concetti. le immagini. il desiderio, exh. cat. (Florence, 1980), 50, 110, 150-51; Ettore Allegri and Alessandro Cecchi, Palazzo Vecchio e i Medici: Guida storica (Florence, 1980), 323-50, especially 326; Michael Rinehart, "A Document for the Studiolo of Francesco I," in Art the Ape of Nature. Studies in Honor of A. W. Janson, ed. Mosche Barasch et al. (New York, 1981), 280-83; and Philippe Morel, "Le Studiolo de Francesco I de'Medici et l'économie symbolique du pouvoir au Palazzo Vecchio," in Symboles de la Renaissance, 3 vols (Paris, 1982), II, 192 and note 48.

3 Rinehart, "A Document," 278, publishes a photograph of the page in question, discovered by Paola Barocchi, and gives the source as the Archivio Storico Fiorentino when, in point of fact, it is located in the Arcnivio di Stato di Firenze.

4 Richard Anthony Scorza, "Vincenzo Borghini (1515-1580) as Iconographic Adviser," Ph.D. diss., Warburg Instituce, 1987. 177, note 28. I wish to thank François Quiviger for kindly sending me a copy of Scorza's Chapter 8, entitled "The Studiolo and Monumental Projects for Francesco de'Medici, 1568-78."

5 I have been able to reconstruct the Scrittoio based on heretofore undiscovered sixteenth-century evidence. While this is not the proper place in which to discuss the particulars (I am preparing a lengthy study on the room), according to my reconstruction Poggi was correct in his placement of eight paintings, four of which are on the main, east wall, two on the opposite west wall, and one each on the north and south walls.

6 On Correggio's Danaë, 1531, and other treatments of the subject, see Madlyn Millner Kahr, "Danaë: Virtuous, Voluptuous, Venal Woman," Art Bulletin, LX, no. 1 (March 1978), 43-55; and recently Cathy Santore, "Danaë: The Renaissance Courtesan's Alter Ego," Zeitschrift für Kunstgeschichte, LIV, no. 3 (1991), 412-27

7 Ovid, Metamorphoses, IV, 604-16, trans. Frank Justus Miller, Loeb Classical Library, 2 vols (1st edn 1916; London and Cambridge, Mass., 1960), I, 220-23.

8 Schaefer, "Studiolo," I, 419-20. Schaefer argued that "Borghini used no specific source but rather ... knew the simple story and decided it would be applicable to the Studiolo invenzione." I do not doube that Borghini began with his trusted Metamorphoses when thinking in terms of "la pioggio d'oro." But as I shall demonstrate, he then accreted a truly astonishing range of sources in order to transform a "simple myth" into a potent political metaphor.

9 Ovid, Amores, II, xix, 27-28; III, iv, 21-22, in Ovid, Heroides and Amores, trans. Grant Showerman, Loeb Classical Library (1st edn 1914; Cambridge, Mass. and London, 1963), 460-61.

10 Apollodorus, Library, II, iv, 1, in The Library, trans. Sir James George Frazer, Loeb Classical Library (1st edn 1921; Cambridge, Mass. and London, 1976), I, 152-55; Horace, Odes, III, xiv, 1 16, in Horace, The Odes and Epodes, trans. C. E. Bennetr, Loeb Classical Library (1st edn 1914; Cambridge, Mass. and London, 1968), 232-33; Hyginus, Fabulae, LXIII, in The Myths of Hyginus, trans. and ed. Mary Grant (Lawrence, 1960), 64.

11 On the Bargello's appellation and function, see Samuel Y. Edgerton, Jr., Pictures and Punishment. Art and Criminal Prosecution during the Florentine Renaissance (Ithaca and London, 1985), 45.

12 Another fresco of the Duke of Athens being handed the Palazzo dei Priori by one of his cronies (Ranieri di Giotto da San Gimignano), "come disleale e traditore della patria," was painted in 1344 by Giottino as a pittura infamante, and was still visible in 1550 when Vasari wrote his Lives; see Giorgio Vasari, Le Vite dé più eccellenti pittori, scultori e architettori, ed. Gaetano Milanesi, 8 vols (Florence, 1878-85), I, 625-26. It is unlikely that Giottino's rendition of the Palazzo della Signoria would have included the bulwarks, as these were the Duke of Athens' additions. This lost fresco is discussed in Edgerton, Pictures and Punishment, 78-82, who also treats Orcagna's fresco on 41, 83-84. I am also drawing on the more recent discussions of Orcagna's fresco in Gert Kreytenberg, "Bemerkungen zum Fresko der Vertreibung des Duca d'Atene aus Florenz," in Musagetes. Festschrift für Wolfram Prinz zu seinem 60. Geburtstag am 5. Februar 1989, ed. Ronald G. Keeks, Frankfurter Forschungen zur Kunst, Band 17 (Berlin, 1991), 151-65; and Nicolai Rubinstein, The Palazzo Vecchio 1298-1532. Government, Architecture, and Imagery in the Civic Palace of the Florentine Republic (Oxford, 1995), 15-17. I wish to thank Adrian Hoch for drawing Rubinstein's book to my attention.

13 Giovanni Boccaccio, La Genealogia de gli dei de gentili ... (Venice, 1581), II, 34v, partially quoted in Millner Kahr, "Danaë," 44. For Boccaccio, Danaë's loss of virginity was due to her lust for gold.

14 For this and the following, I am relying on Giovanni Villani, Cronica, 8 vols (Rome, 1980), VII, 5-54; Gene A. Brucker, Florentine Politics and Society 1343-1378, Princcton Studics in History, 12 (Princeton, 1962), 7-9; and Rubinstein, Palazzo Vecchio, 15-17.

15 Villani, Cronica, VII, 54: "avea con inganno e tradimento usurpata la libertà sopra il comune e popolo di Firenze ..." This and the following translations are my own. 
16 On the codpiece as symbol, see Konrad Eisenbichler, "Bronzino's Portrait of Guidobaldo II della Rovere," Renaissance and Reformation, XXIV, no. 1 (Winter 1988), 21-33; and recently Patricia Simons, "Alert and Erect: Masculinity in Some Italian Renaissance Portraits of Fathers and Sons," in Gender Rhetorics: Postures of Dominance and Submission in History, ed. Richard Trexler (Binghamton, 1994), 169-73.

17 Detlef Heikamp, with a contribution by Guglielmo Galli, "Ammannati's Fountain for the Sala Grande of the Palazzo Vecchio in Florence," in Fons Sapientiae. Renaissance Garden Fountains, Dumbarton Oaks Colloquium on Landscape Architecture V, ed. E. B. MacDougal (Washington, 1978), 125-30, for this and the following readings of the Fountain of Juno. On 125. Heikamp states "A free approach to the conjunction of antique and Christian traditions is often found in Vasari's decorations in the Palazzo Vecchio, and so, too, it appears in the conception of Ammannati's fountain," though, curiously, he offers no further Christian parallels in his analysis of the Fountain of Juno than that just cited in my text. I provide further parallels, below.

18 Florian Härb, "A New Drawing by Giorgio Vasari," Master Drawings, XXXIII, no. 1 (Spring 1995), 51-55.

19 Vasari-Milanesi, Le Vite, VIII, 70: "Questi, Signor mio [Francesco], son coloro che per oro e doni sono sforzaci dalla cortesia e liberalità a far la volontà del duca nostro, il quale, in pioggia d'oro passando per i luoghi più segreti, trae di quelli, cioc̀ de luoghi impossibili, ogni persona per donativi e per amore a' suoi servigj per onorarlo." This passage is quoted in Härb, "New Drawing," 55, note 13.

20 Rubinstein, Palazzo Vecchio, 17.

21 Rubinstein, Palazzo Vecchio, 96

22 If Traballesi's tower refers first and foremost to Hyginus' "stonewalled prison," then the concetto of the Rain of Gold most certainly has an astrological foundation. I shall address this idea, as well as alchemical ones, in my larger trearment of the Scritroio.

23 On this topos, see Janet Cox-Rearick, Dynasty and Destiny in Medici Art. Pontormo, Leo X, and the Two Cosimos (Princeton, 1984), 79-82, who also identifies the roses as specifically Medicean symbols.

24 Ellen D. Reeder, Pandora's Box. Women in Classical Greece, exh. cat. (Baltimore, 1995), 195.

25 Julian Kleimann, "Zeichnungsfragmente aus der Werkstatt Vasaris und ein Unbekanntes Programm Vincenzio Borghinis für das Casino Mediceo in Florenz - Borghinis 'inventioni per pitture fatte' -," Jahrbuch der Berliner Museen. Jahrbuch der Preußischen Kunstsammlungen, Neue Folge, XX (1978), 177-78. $I$ intend to address the botanical symbolism of the Scritcoio.

26 Vasari-Milanesi, Le Vite, VIII, 45, with regard to the "Sala della Dea Opi," upstairs in the Palazzo della Signoria. Ops also guarded the home in the manner of the Lares and Penates, the ancient Roman household gods. Hence, she guards Cosimo's home, the Palazzo della Signoria. On the symbolism of the Mater larum, see Erich Newmann, The Great Mother. An Analysis of the Archetype, Bollingen Series XLVII, trans. Ralph Manheim (New York, 1955), 283.

27 Vincenzo Cartari, Le Imagini con la spositione de $i$ Dei de gli antichi (Venice, 1556), 42

28 Although scholars wish to credit Vasari or "his school" for drawing the imprese on Borghini's notebook covers, I believe that they were created by the Prior himself, given his own drawings for the wedding of Francesco I and Giovanna contained in Biblioteca Nazionale Centrale, Firenze, ms. II.X.100. For the contrary view, see Lo storiografo dell'arte nella Toscana dei Medici, eds Laura Corti, Margaret Daly Davis, Charles Davis, Julian Kliemann, in Giorgio Vasari. Principe, letterati e artisti nelle carte di Giorgio Vasari, Pittura vasariana dal 1532 al 1554. Sottochiesa di S. Francesco, exh. cat., La Toscana nel'500 (Florence, 1981), 161 62.

29 I am drawing on the description of Flora penned by Cosimo Bartoli in 1567 and reprinted in the context of Ammannati's Fiorenza in Heikamp, "Ammannati's Marble," in Fons Sapientiae, 129.

30 See Allegri and Cecchi, Palazzo Vecchio, 331, 68, for illustrations of Casini's Forge of Vulcan and Vasari and Gherardi's Allegory of Fire, respectively.

31 Schaefer, "Studiolo," I, 346.

32 I am relying on Giovambatista Adriani, Istoria dé svoi tempi.. Divisa in Libri Ventidve Di Nuouo Mandata in Luce con li sommarii, e tavola delle cose piu notabili (Florence, 1583), 182, for Cosimo's admittance to the Order; and Karla Langedijk, The Portraits of the Medici 15th-18th Centuries, 3 vols (Florence, 1981-87), II, 851, for Francesco's admittance (cf. I, 407, for Cosimo's).

33 I am quoting Vincenzo Borghini's description of Plutus in his invenzione for the Scrittoio, in Der Literarische Nachlass Giorgio Vasaris, eds Karl Frey and Herman-Walther Frey, 3 vols (Munich, 1930), II, 891: "piena di pensieri come sono gli avari"; Lucian's Plucus is discussed in Dora and Erwin Panofsky, Pandora's Box. The Changing Aspects of a Mythical Symbol (London, 1956), 46-47. Plutus' copper vase is documented in A. S. F., Scrittoio Fortezze e Fabbriche, Fabbriche Medicee 5, 30r, transcribed and discussed in Michael Rinehart, "A Drawing by Vasari for the Studiolo of Francesco I," Burlington Magazine, CVI, no. 732 (February 1964), 76 and note 23.

34 Cartari, Le Imagini, 54: "la pace è conseruatrice delle ricchezze, e la guerra le dißipano."

35 Eugenio Battisti, "Il Barocco non è passato invano," in Lo Studiolo di Francesco I dei Medici e il suo doppio, ed. Giovanna Portoghesi Massobrio (Rome, 1986), 18, perceptively noted that "I quadri [in the Scrittoio] ... sembrano elegantissimi frontespizi di libri." However, he did not pursue the implications of this observation. I shall do so in considerable detail in my forthcoming study on the Scrittoio.

36 Reeder, Pandora's Box, 195. While one would expect to find this analogy in Agnolo Firenzuola, Dialogo delle Bellezze delle Donne (Venice, 1552), since he compared a woman's body to a vase, it 
is not forthcoming. Firenzuola's analogy is discussed in Elizabeth Cropper, "On Beautiful Women, Parmigianino, Petrarchismo, and the Vernacular Style," Art Bulletin, LVIII, no. 3 (Seprember 1976), 374-76.

37 Discussed in Cropper, "Beautiful Women," 381.

38 Vasari-Milanesi, Le Vite, VIII, 20-21: "vaso grande che lo rovescia in giù, pieno di gioie, vasi d'oro e d'argento, collane e mitrie da papi, corone da imperadori e re ... la Grazia del grande Dio." Significantly, this painting commemorates Cosimo's birth; see Claudia Rousseau, "Cosimo I de'Medici and Astrology: The Symbolism of Prophecy," Ph.D. diss., Columbia University, $1983,335$.

39 On the baton of command, see Malcolm Campbell, "Il Ritratto del Duca Alessandro de'Medici di Giorgio Vasari: contesto e significato," in Giorgio Vasari tra decorazione ambientale e storiografia artistica, Convegno di studi, Arezzo, 8-10 ottobre 1981, ed. Gian Carlo Garfagnini (Florence, 1985), 353.

40 Raymond Klibansky, Erwin Panofsky and Fritz Saxl, Saturn and Melancholy. Studies in the History of Natural Philosophy, Religion and Art (Cambridge, 1964), 322. Of course, Acrisius' model, the Penseroso, is also melancholic. Further, the seascape in the Rain of Gold contributes to the symbolism of Saturnine melancholy. This is hardly coincidental, given that Melancholy is situated on the vault directly above Traballesi's painting. Moreover, it will become clear as my analysis progresses that Borghini's historical "la pioggio d'oro" contains melancholic resonances.

41 Piero Bargellini, Florence the Magnificent. A History, trans. B. Nicholis, R. McPierce, 4 vols (Florence, 1980), II, 330, with regard to Alessandro de'Medici's status.

42 I am drawing on the recent research in Mario Scalini, "Larmamento difensivo dei contendenti della guerra di Siena," in $L a$ fortuna di Cosimo I. La battaglia di Scannagallo, exh. cat. (Arezzo, 1992), 98-104. But see Cox-Rearick, Dynasty, 288, for Cosimo's more youthful appearance.

43 Adriani, Istoria, 83, for this and the following. It is important to recognize that Vasari and/or Stradano depicted Adriani's portrait in the Triumph after the Victory over Siena in the Sala Grande, ca. 1563-65, because he had assisted with the historical details; see Allegri and Cecchi, Palazzo Vecchio, 241. It is entirely likely that Adriani assisted Borghini in the same fashion for the Scrittoio.

44 Adriani, Istoria, 69: "Medesimamente con gran pompa, \& allcgrezza celebrò il battesimo del suo Primogenito, tenendolo al sacro fonte Don Giouanni di Luna in nome dell'Imperadore, \& voi altro Signore in nome della Reina d'Vngheria, e ciò con gran piacere di tutta la Città." Adriani also discusses Alessandro Buonaccorsi being thrown into jail by Cosimo at the time of Francesco's birth.

45 Agostino Cesaretti, Istoria del Principato di Piombino e osservationi intorno al diritti della Corona di Toscana sopra i castelli di Valle e Montione, Historiae Urbium et Regionum Italiae Rariores XCIII, Nuova Serie IX (1st edn 1788; Bologna, 1974), 97, 104. An extremely useful d'Appiani family tree is contained in Il Potere e la memoria. Piombino stato e città nell'età moderna, ed. Sovrintendenza Archivistica per la Toscana, exh. cat. (Florence, 1995), pull-out at the back of the book. See also Goffredo Ademollo Valle, Rosso Fiorentino a Piombino. Il ritratto di Jacopo $\checkmark$ Appiani (Piombino, 1994), 17.

46 Adriani, Istoria, 115-16; compare Cesaretti, Istoria, 113-14, who reveals that Jacopo $\mathrm{V}$ "taught him the duties of the Christian religion and baptized him, considering him as a son [fatto istruire ne'doveri della Cristiana Religione lo fece battezare, considerandolo come suo figlio]."

47 Adriani, Istoria, 117: "Architetri, e maestri di fabbricare del Dominio di Firenze, e gran numero di Contadini."

48 Adriani, Istoria, 133: "non si trouando in Piombino ne huomini, ne strumenti che vi potessero mettere in opera, e del continuo si mandarono denari al Signore, accioche per sua mano passassero i pagamenti de'soldati, e de' fabbricanti."

49 Adriani, Istoria, 133. The quotation is taken from E. Rocchi, Le fonti storiche dell'Architettura militare (Rome, 1908), 323: "bel castello quadrilatero bastionato."

50 Diodorus Siculus, History, V, 13, 1-2, in Diodorus of Sicily, trans. C. H. Oldfather, Loeb Classical Library, 12 vols (1st edn 1939; Cambridge, Mass., and London, 1970), III, 130-31; Pliny, Natural History, III, vi, 80-81, trans. H. Rackham, Locb Classical Library, 12 vols (1st edn 1940; London and Cambridge, Mass., 1967), II, 58-61.

51 Strabo, Geography, V, ii, 6, in The Geography of Strabo, trans. Horace Leonard Jones, Loeb Classical Library, 8 vols (1st edn 1923; Cambridge, Mass., and London, 1969), II, 354-57.

52 Described in Giovambatista Cini, Descrizione dell'apparato fatto in Firenze per le nozze dell'illustrissimo ed eccellentissimo Don Francesco de'Medici Principe di Firenze e di Siena e dela Serenissima Regina Giovanna d'Austria, in Vasari-Milanesi, Le Vite, VIII, $536-$ 38; and Domenico Mellini, Descrizione dell'Entrata Della Serenissima Reina Giovanna d'Austria Et dell'Apparato fatto in Firenze nella venuta, o per le felicissime nozze di S. Altezza Et dell'Illustrissimo, \& Eccellentissimo S. Don Francesco de Medici, Prencipe di Firenze, \& di Siena (Florence, 1566), 44-46.

53 Andromeda symbolizes Florence in Benvenuto Cellini's relief of Perseus rescuing Andromeda, located at the base of his Perseus and the Medusa, 1545-54. See John Pope-Hennessy, Cellini (New York, 1985), 168-69. In my estimation, Borghini drew inspiration from Cellini's masterpiece when composing his concetto for the eastern end of the Scrittoio.

54 Scott Schaefer, "Europe and Beyond: On Somc Paintings for Francesco's Studiolo," in Firenze e la Toscana dei Medici nell'Europa del'500, 3 vols (Florence, 1983), III, 933-38, for this and the following. Pietro Cieza, La Prima Parte dell'Historie del Perv. Dove si tratta d'ordine delle Prouincie, delle Città nuoue in quel Paese edificate, i riti, \& costumi de gli Indiani ... (Venice, 1560), 195-96v, discusses the Spanish discovery of Cerro de Potosì in 1547 in a chapter entitled "How the mines of Potosì were found, and on the riches of silver that were extracted, the likes of which had neither been seen nor heard of before [Come 
furono trovatele minere de Potosi, dalle quali sono state cauate ricchezze d'argento non mai uedute, ne udite. Capo CIX [emphasis mine]]." Although it seems odd that Zucchi depicted the silver mines of Cerro de Potosi for a narrative concerning the extraction of gold from the earth, I do not doubt that the figures in the background are Spaniards. Nor do I doubt that they are part of an imperial retinue in South America, for Zucchi's geography evokes the New World.

55 Illustrated in Isola d'Elba: geologia, flora, fauna, storia, arte, ambiente, ed Giorgio Giubelli (Milan, n.d.), 96.

56 In a general way, the distinctive dome and lantern crowning the central structure, but not the drum, evoke the dome and lantern crowning the Sanctuary of the Madonna delle Grazie, an early cinquecento sanctuary located near the water, a few kilometres from Capoliveri. Borghini could well have been drawing a parallel between this structure and that actually represented from life. I shall explain my reasons for making this suggestion in a subsequent note.

57 The island's bridge and architecture also bear a certain resemblance to Piombino as depicted in Rosso Fiorentino's Jacopo $\mathrm{V}$ d'Appiano, in Valle, Rosso, 33. If Traballesi intended such resemblance, then Borghini would have been commenting on Cosimo's Elban (and Florentine) control of the "insular" Piombino.

58 Borghini referred to his programme for the Scrittoio as a "marvellous chain of nature that preserves all [mirabil catena della natura che conserua il tutto]" in his invenzione, published in Der Literarische, eds Frey and Frey, II, 889.

59 On this method, see Charles Hope, "Historical Portraits in the 'Lives' and in the frescoes of Giorgio Vasari," in Giorgio Vasari, ed. Garfagnini, 321-38.

60 I am drawing on the legalese in Riguccio Galluzzi, Istoria del Granducato di Toscana sotto il governo della Casa Medici ... (1 st edn 1781; Milan, 1974), I, 4.: "Capo primario della città di Firenze e suo Dominio." For the portraits of Ottaviano de'Medici in the Sala di Cosimo I, see Allegri and Cecchi, Palazzo Vecchio, 143, 146. In 1540 Vasari painted another portrait of Ottaviano de'Medici in his Supper of St. Gregory in the refectory of S. Michele in Bosco, Bologna, identified in Cox-Rearick, Dynasty, 245, note 45

61 Langedijk, Portraits, III, 1557, lists the portraits in his collection, or in the collection of his heirs, but does not pay any attention to portraits of Ottaviano himself. She also directs the reader to the study of A. M. Bracciante, Ottaviano de'Medici e gli artisti (Florence, 1984).

62 For Ottaviano's imprisonment, see Bracciante, Ottaviano, 112 , note 136, who draws on Benedetto Varchi's Storia fiorentina. I am relying on Lorenzo Cantini, Vita di Cosimo de'Medici Primo Granduca di Toscana (Florence, 1805), 111-12, note 2; and E. Grassellini and A. Fracassini, Profili Medicei. Origine, sviluppo, decadenza, della famiglia medici attraverso i suoi componenti (Florence, 1982), 65-66, for this and the following.

63 See my "Perseus and the Medici," Storia dell'arte, LXXXVII (May-August 1996), 168-87.
64 In fact, Acrisius' form bears a certain resemblance to Pope Clement VII's in Bandinelli's Clement VII crowning Charles V Holy Roman Emperor. While it would have been out of the question to compare the Medici pope to the Duke of Athens and Jacopo $\mathrm{V}$, it might not have been altogether unreasonable to allude to his captivity during the Sack of Rome. But, as the reader has probably recognized, Borghini reserved the essential references to the Udienza for the opposite wall of the Scrittoio, featuring Eleonora di Toledo and the element of air. Unfortunately, I cannot demonstrate this statement in the current context.

65 For Francesco del Prato's medal representing Alessandro-Perseus walking on water, see Pope-Hennessy, Cellini, 168-69. For the Queen of Hungary's legate, refer to the Adriani passage quoted in my text, above.

66 See note 7 , above.

67 Since the uppermost reaches of the Sienese Duomo bear a general resemblance to the sanctuary of the Madonna delle Grazie (as Elban topography bears a general resemblance to Sienese topography), this dome could well allude to Danaë-the Virgin Mary as a vessel of balsam, a vessel of Grace. Of course, as the city dedicated to the Virgin, such symbolism is already inherent in the Sienese Duomo.

68 Discussed and illustrated in Langedijk, Portraits, II, 1077-78.

69 For this and the following, I am drawing on the research of Gabrielle Langdon, "Pontormo and Medici Lineages: Maria Salviati, Alessandro, Giulia and Giulio de'Medici," RACAR, XIX, 1-2 (1992), 27-29; and Grassellini and Fracassini, Profili Medicei, 94.

70 The basic information on this Order is reported in Paul William Richelson, Studies in the Personal Imagery of Cosimo I De'Medici, Duke of Florence (New York, 1978), 147-51.

71 For the soldo, see Richelson, Studies, 151.

72 Richelson, Studies, 149, was one of the first modern scholars to recognize that these historical confluences are celebrated in Medicean art.

73 Galluzzi, Istoria, 69: "Mori finalmente Jacopo V d'Appiano ..."

74 I am purposefully avoiding the morass concerning the identity of the architect, since it is not significant in the current context. Still, see Rino Manetti, Portoferraio e le sue antiche fortificazioni (1st edn 1966; Portoferraio, 1995), 45-54; Giuseppe M. Battaglini, Portoferraio Medicea, in Livorno: progetto e storia di una città tra il 1500 e il 1600, exh. cat. (Pisa, 1980); and Giovan Battista Belluzzi, Il Trattato delle Fortificazioni di Terra, Biblioteca Riccardiana di Firenze, ms. Riccardi 2587, ed. Daniela Lamberini, in Il Disegno Interrotto. i trattati medicei d'architettura, Documenti inediti di cultura toscana (Florence, 1980), IV, 37590.

75 Based on Vasari and Stradano's Victory of Cosimo I at Montemurlo once again (my fig. 10), I would provisionally identify the elderly bearded figure standing behind Cosimo-state treasurer as Otto da Montauto. See Allegri and Cecchi, Palazzo Vecchio, 143, for his placement beside Alessandro Vitelli (in turn, located beside Ottaviano de'Medici). Parenthetically, Pirro Colonna (lo- 
cated to the other side of Ottaviano) was also involved in the affairs of Elba, but he seems to have been excluded from the Rain of Gold.

76 The document, dated 29 May 1557 and penned in London, England, is reprinted in Licurgo Cappelletti, Storia della Città e stato di Piombino dalle origini fino all'anno 1814 (Livorno, 1897), 476-78.

77 J. R. Hale, Florence and the Medici. The Pattern of Control (Great Britain, 1977), 131, 132.

78 Vasari-Milanesi, Le Vite, VIII, 41: "Questo non è altro che, mosso a compassione Carlo V di questa travagliata Italia, conformo nel nido paterno il duca Cosimo, dopo la morce del duca Alessandro, ritenendolo in casa, con darli la signora duchessa, madre vostra, in compagnia per isposa, acciò godendo in felicità questo paese, e guardandolo con le forze sue grandissime, per farlo crescare di dominio gli fa venire sotto il governo l'isola dell'Elba e lo stato di Siena."

79 Richelson, Studies, 148.

80 Vasari-Milanesi, Le Vite, VIII, 46-47, states that Ops' lions are "a sign of Florence, that is, of her citizens [segno di Fiorenza, cioè da'suoi cittadini ...]" Compare Schaefer, "Studiolo," I, 346.
81 My reading of Marsili's painting is consonant with the findings of Henk Th. van Veen, "Republicanism in the Visual Propaganda of Cosimo I de'Medici," Journal of the Warburg and Courtauld Institutes, LV (1992), 200-09; and idem, "Republicanism, ' not 'Triumphalism.' On the political message of Cosimo I's Sala Grande," Mitteilungen des Kunsthistorischen Instituts in Florenz, XXXVII, no. 2/3 (1993), 475-80.

82 Cartari, Le imagini, 85v: "nulla pò Venere senza Baccho."

83 Marco Collaretta, "Palazzo Vecchio e i Medici: Guida storica di E. Allegri, A. Cecchi," Bollettino d'arte, VIII (October-December 1980), 117, has noted the quotation of Michelangelo's Bacchus in another context pertaining to Francesco I's Scrittoio.

$84 \mathrm{La}$ Stella, or the Star, is located at the entrance to the port of Portoferraio, elevated behind La Linguella. When standing within La Stella, it is possible to see the even more elevated fortification of Il Falcone. I would therefore identify the miniscule fortification atop Marsili's most distant mountain as Il Falcone.

85 Richard Trexler and Mary Elizabeth Lewis, "Two Captains and Three Kings," Studies in Medieval and Renaissance History, IV (1981), 126-27, explain that the Medici had been called "lights" since the time of Lorenzo il Magnifico. 